\title{
Fiscal Rules for Natural Disaster- and Climate Change-Prone Small States
}

\author{
Ryota Nakatani (D)
}

check for

updates

Citation: Nakatani, R. Fiscal Rules for Natural Disaster- and Climate Change-Prone Small States. Sustainability 2021, 13, 3135. https://doi.org/10.3390/su13063135

Academic Editor: Hannu Schadewitz

Received: 5 February 2021

Accepted: 8 March 2021

Published: 12 March 2021

Publisher's Note: MDPI stays neutral with regard to jurisdictional claims in published maps and institutional affiliations.

Copyright: (C) 2021 by the author. Licensee MDPI, Basel, Switzerland. This article is an open access article distributed under the terms and conditions of the Creative Commons Attribution (CC BY) license (https:/ / creativecommons.org/licenses/by/ $4.0 /)$.
International Monetary Fund, 700 19th Street NW, Washington, DC 20431, USA; rnakatani@imf.org

\begin{abstract}
How should small states formulate a countercyclical fiscal policy to achieve economic stability and fiscal sustainability when they are prone to natural disasters, climate change, commodity price changes, and uncertain donor grants? We study how natural disasters and climate change affect long-term debt dynamics, and we propose cutting-edge fiscal policy rules. We find the primacy of a recurrent expenditure rule based on non-resource and non-grant revenue, interdependently determined by government debt and budget balance targets with expected disaster shocks. This innovative fiscal rule is classified as a natural disaster-resilient fiscal rule, which comprises a plethora of new advantages compared to existing fiscal rules. This new type of fiscal rule can be called as the third-generation fiscal rule. It encompasses natural disasters and climate change, uses budget data only, avoids the need for escape clauses, and operates on a timely basis. Our rule-based fiscal policy framework is practically applicable for many developing countries facing an increasing frequency and impact of devastating natural hazards, and climatic change.
\end{abstract}

Keywords: fiscal rule; natural disaster; climate change; Pacific Islands; debt sustainability; recurrent expenditure; countercyclical fiscal policy; Papua New Guinea; resource revenue; grants

\section{Introduction}

How should small, fragile islands formulate fiscal policy when vulnerable to various shocks such as natural disasters, climate change, commodity price fluctuations, or uncertain donor grants? Fiscal policy rules help mitigate the effects of such shocks on the economy. We develop an analytical framework for a rule-based fiscal policy to ensure fiscal sustainability and economic stability in countries most prone to natural disasters, with a focus on the Pacific Islands. Our contributions are: (1) to show how permanent natural disaster shocks or climate change affect the sustainable, steady-state debt-to-GDP ratio; (2) to propose a recurrent expenditure rule interdependently determined by government debt and budget balance targets, incorporating probabilistic disaster shocks; and (3) to define a recurrent expenditure rule robust against natural disasters, commodity price fluctuations, and uncertain grant revenues. Recurrent expenditure rules are defined as the ratio of government expenditure excluding public investment and interest expense to the stable revenue (i.e., government revenue excluding volatile resource revenue as well as uncertain grant revenue). In this way, we could safeguard investment required in the aftermath of catastrophic natural disaster events.

Fiscal policy in the Pacific needs to address region-specific factors in addition to basic objectives. In principle, fiscal policy has three functional objectives: first, stabilize economic cycles via countercyclical policy; second, redistribute national wealth across sectors and reduce poverty; and, third, support sustainable economy via public goods and services. The Pacific Islands have large infrastructure gaps, and infrastructure needs to be made more climate/disaster resilient because natural disasters and climate change, including storms, earthquakes, volcanic activity, floods, droughts, and landslides, affect the Pacific island economies [1]. The economic impacts of frequent natural disasters are intense. The cyclones during 2015-2016 caused economic damage equivalent to $25 \%$ of 
GDP in Fiji and 64\% in Vanuatu. A severe drought and commodity price declines in Papua New Guinea (PNG) reduced agricultural and mining productions as well as fiscal and foreign exchange revenues [2,3]. The biggest earthquake in 100 years hit PNG in 2018 and suspended liquefied natural gas (LNG), oil, and gold mining operations, lowering economic growth sharply.

Another relevant factor for the Pacific Islands is uncertain donor grants. Pacific island countries rely heavily on foreign aid, and they bear the burden of more acute disasters compared to the Caribbean islands [4]. Remittances are equally important financial flows to mitigate the impact of natural disasters. In the face of severe natural disasters, migrants from the Pacific Islands send remittances to the home country to support their community [5]. Migrants' remittances respond to hurricane exposure more in the poorer countries [6]. There is huge potential for remittance finances to be an alternative source of climate finance for the Pacific Islands [7]. Moreover, natural disasters are likely to affect poor households more as they do not have sufficient resources to insure themselves or to recover from the losses. Poor households are more vulnerable to disasters because they are more likely to reside closer to areas that are exposed to disasters, such as coastal areas, and they do not have the ability to migrate [8].

The Pacific Islands experience higher macroeconomic volatility because of less economic diversification, which increases their vulnerability to terms-of-trade or commodity price shocks. Smaller developing countries face larger output declines following a disaster than bigger countries [9]. Moreover, the default fiscal framework in many disaster-prone states is procyclical since they have de-facto balanced budget rule under limited borrowing capacity (i.e., revenue volatility leads to expenditure volatility). The fiscal authorities face difficulty in adjusting to macroeconomic shocks due to the lack of timely macroeconomic data, which weakens the scope for countercyclical measures. The fiscal balance positively correlates with output in developing countries $[10,11]$ and $65 \%$ of them show a procyclical fiscal policy [12]. Fiscal policy is procyclical in developing countries due to natural disasters [13]. Hence, they need to frame fiscal rules that insulate spending from revenue volatility.

This paper studies fiscal rules in small islands prone to natural disasters. First, we observe the debt-to-GDP ratio maximizing the primary balance from data on the Pacific Islands. Second, we show how to calibrate a debt-to-GDP target in the event of natural disasters. Third, the impact of unexpected climate change shocks on debt sustainability is analyzed. Fourth, the debt target with probabilistic natural disaster shocks is connected to fiscal balance, expenditure, and revenues. Finally, we recommend a recurrent expenditure rule, which has several advantages: it allows government expenditure required for recovery of damages by disasters; it does not require potential GDP growth rates difficult to estimate for small islands; and it is free from a prerequisite for expenditure growth rule (initial fiscal position is in the steady state). We provide an application of these rules to PNG because it has all characteristics of the Pacific small states: susceptibility to frequent and various natural disasters, commodity exporters, reliance on uncertain grants, etc.

Fiscal rules reduce procyclicality of economy and maintain fiscal sustainability while meeting infrastructure needs. They also control the pressure to overspend during good times and ensure fiscal responsibility, prudence, and debt sustainability. A debt rule critically maintains long-run fiscal sustainability. Large-scale natural disasters significantly increase the probability of a sovereign debt default [14]. This is important because the Pacific island countries have experienced frequent sovereign defaults in history (Figure 1). To keep the debt-to-GDP ratio under certain limits, a budget balance rule should constrain the size of the budget deficit as an operational guide, backed by expenditure or revenue rules. Since expenditure is more controllable by the government than revenue, the expenditure policy is desirable to achieve a budget balance rule. Furthermore, investment-friendly rules are important for the Pacific Islands because of large infrastructure needs amplified by natural disasters/climate change. On the revenue side, it may be important to set a floor for revenue, so that the government can secure adequate revenues for policy objectives, and 
to determine the use of windfall revenues, especially for commodity exporters. Note that both revenue and expenditure have automatic stabilizer effects. Automatic stabilizers are actually located on the expenditure side in advanced countries [15]. This is also applicable to the Pacific Islands because countercyclical fiscal policy is mainly caused by inertia in discretionary expenditure: governments do no lay off officials, teachers, policemen or nurses during economic downturns, although some expenditure items that contribute to countercyclicality such as social insurance and unemployment benefits are not well developed in small states compared to advanced countries.

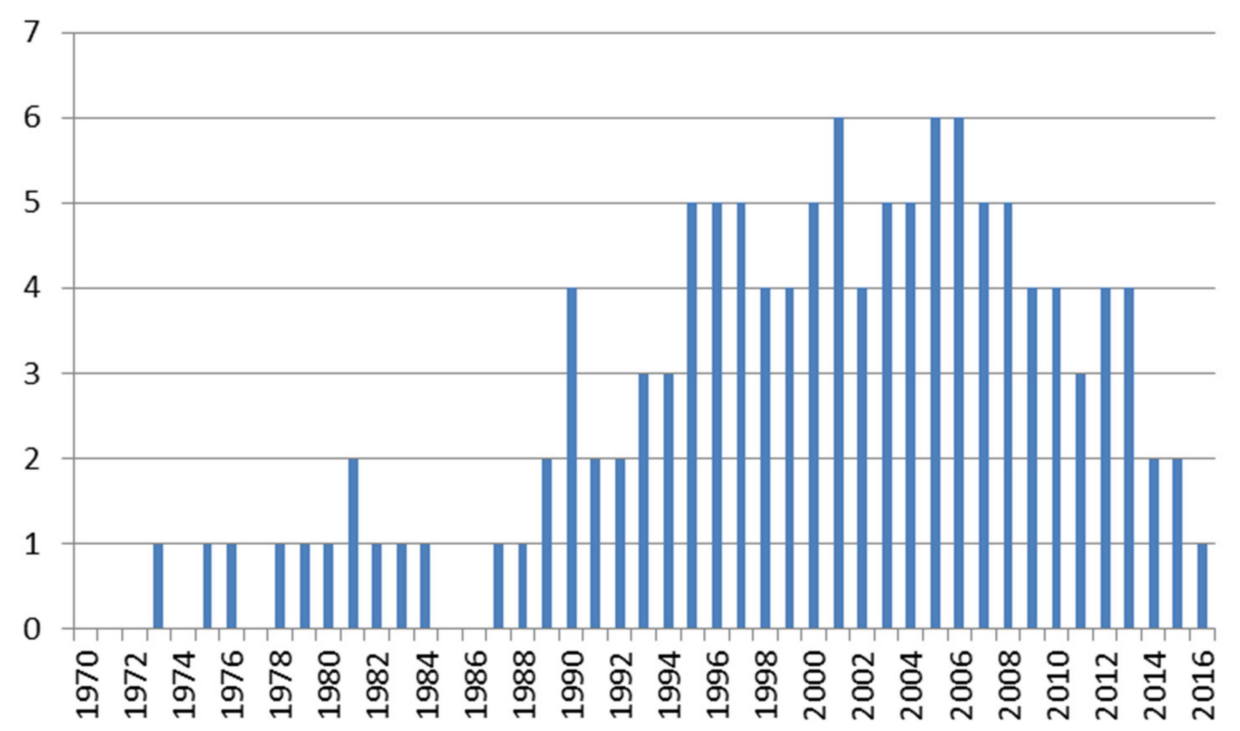

Figure 1. Sovereign Default Episodes in Selected Pacific Island Countries. Note: Sample countries are Fiji, Nauru, Papua New Guinea, Samoa, Solomon Islands, Tonga, and Vanuatu. Data on the other Pacific island countries are not available. Source: Bank of Canada Sovereign Default Database [16].

External and internal constraints and economic shocks affect the design and application of fiscal rules. Pacific Islands face binding external borrowing constraints and cannot issue sovereign bonds internationally to prepare for future natural disasters. Natural disasters have persistent negative effects on economic growth over the medium term in countries with less developed financial sector [17]. Most islands have inadequate reserves to cover catastrophic disasters. Not only permanent shocks (e.g., climate change) but also changes in the long-term interest rates or in the fiscal regimes (e.g., new resource projects, fishing agreements) affect fiscal sustainability. Thus, we should consider how they change the implications of fiscal rules and the ability to cope with substantial shocks. Lastly, operational simplicity is preferable when designing the fiscal rules for the Pacific Islands, given their institutional capacity.

\section{Literature Review}

\subsection{Literature on Fiscal Rules}

Fiscal rules are of five types: (1) debt rules; (2) budget balance rules; (3) expenditure rules; (4) revenue rules; and (5) cash buffer rules. Key objectives as well as pros and cons of each fiscal rule are discussed below and shown in Table 1.

The key objective of debt rules is fiscal sustainability. Debt rules set the limits or targets for public debt in percent of GDP to ensure debt sustainability. Despite their easiness to communicate, debt rules do not provide clear short-run operational guidance.

Budget balance rules give operational guidance to achieve the debt target/rule, and they are also easy to communicate with public. A budget balance rule constrains fiscal policy and has output-stabilizing effects if the target is expressed in cyclically-adjusted terms $[18,19]$. Fiscal rules are negatively related to output volatility, where this effect is channeled through a reduction in fiscal policy volatility [20]. Balanced budget and expen- 
diture rules are most effective in reducing fiscal procyclicality in emerging markets [21]. Government efficiency is also important for the effectiveness of fiscal rules to reduce procyclicality of fiscal policy [22]. Multiple fiscal rules enhance fiscal solvency [23]. The introduction of a balanced budget rule is associated with lower government debt-to-GDP ratios and lower probability of a sovereign debt crisis [24]. This is achieved by decreasing government expenditure. Budget balance rules and expenditure rules have significant discipline enhancing effects in developing countries [25].

Table 1. Fiscal rules or targets in the Pacific Islands.

\begin{tabular}{|c|c|c|c|}
\hline Type of Fiscal Rule or Target & Pros & Cons & Countries Using the Rule or Target \\
\hline Debt Rule & $\begin{array}{l}\text { Debt Sustainability; } \\
\text { Easy Communication }\end{array}$ & No Operational Guidance & $\begin{array}{l}\text { Cook Islands; Fiji; Papua New Guinea; } \\
\text { Samoa; Solomon Islands; Tonga; Vanuatu }\end{array}$ \\
\hline Budget Balance Rule & Effective & Procyclicality & Cook Islands; Palau; Samoa; Vanuatu \\
\hline Golden Rule & Link to Debt & Creative Accounting & Solomon Islands \\
\hline Permanent Income Hypothesis & Intergenerational Equity & Hard to Calculate & Papua New Guinea \\
\hline Expenditure Rule & $\begin{array}{l}\text { Effective; Monitoring; } \\
\text { Countercyclicality }\end{array}$ & $\begin{array}{l}\text { Not Directly Linked to } \\
\text { Debt Sustainability }\end{array}$ & Cook Islands \\
\hline Personnel Emolument Rule & $\begin{array}{c}\text { Targeted; } \\
\text { Simplicity; } \\
\text { Operational Guidance }\end{array}$ & $\begin{array}{l}\text { Narrow Coverage; Evasion to } \\
\text { Unconstrained Category }\end{array}$ & Cook Islands; Papua New Guinea; Tonga \\
\hline Recurrent Spending Rule & $\begin{array}{c}\text { Broad Coverage; } \\
\text { Development Needs }\end{array}$ & $\begin{array}{l}\text { Not Directly Liked to } \\
\text { Debt Sustainability }\end{array}$ & - \\
\hline Revenue Rule & Automatic Stabilizer & Procyclicality & Tonga; Timor-Leste \\
\hline Cash Buffers Rule & $\begin{array}{l}\text { Economic Stabilization; } \\
\text { Resilience }\end{array}$ & Opportunity Costs & Cook Islands; Solomon Islands; Tonga \\
\hline
\end{tabular}

Expenditure rules are effective for macroeconomic stabilization. Expenditure rules are more effective than revenue rules because government revenue is more difficult to target or effectively control. The effectiveness of expenditure rules is supported by the empirical literature. For instance, countries that have expenditure rules typically have higher primary balances and lower primary spending than countries without such rules [26]. Expenditure rules are easy to understand, monitor, and enforce, as the government directly controls the expenditure. Caps on expenditure growth (in line with potential growth) are an operational target well under control of policy-makers, being more transparent and more resilient to measurement errors. Cons of expenditure rules are that they may reduce incentives to mobilize revenues.

However, capping expenditure growth is not suitable for the Pacific Islands. An expenditure growth rule related to potential GDP should be applied only when the initial fiscal position is deemed appropriate. Potential GDP is difficult to estimate for Pacific Islands, and it is hard to believe that they are currently close to steady-state revenue-to-GDP ratios because the increasing frequency and impacts of natural disaster change steady-state parameters. Moreover, capping expenditure growth constrains government expenditure required for recovery of damages caused by disasters. Therefore, we analyze the new type of expenditure rule which is linked to the source of revenue.

The practical way to determine fiscal rules is to begin with a debt ceiling or target. Public expenditure and budget balance should be countercyclical to economic cycles for stabilization. Thus, budget balance can be positive or negative in the short run. However, in the long term, fiscal policy should ensure the debt sustainability. Otherwise, governments face fiscal crises and a debt overhang could constrain government activities.

What is a reasonable level for debt ceiling? Although few studies have investigated the debt threshold for the Pacific Islands, the empirical literature suggests that the debt limit for other developing countries is broadly between $35 \%$ and $55 \%$ of GDP. Panel threshold analysis reveals debt thresholds of $40-55 \%$ for non-Latin American and 35\% for Latin American countries [27]. After public debt exceeds a certain threshold level (55\% of GDP), 
it is negatively correlated with economic activity in Malaysia [28] and in the Caribbean [29]. The primary balance-maximizing debt level in emerging markets is around 50\% of GDP [30]. In contrast, the debt ratio threshold, at which fiscal rules become less relevant for the primary balance is higher for the European Union (EU) countries [31]. Another related concept is debt-growth nexus [32]. For instance, debt threshold for economic growth is around debt-to-GDP ratio of 30 percent [33], whereas growth-maximizing debt level is 50 percent of GDP in the Euro area and 66 percent in OECD countries [34].

Apparently, fiscal rules incorporating natural disasters or climate change have not been analyzed. Instead, natural disaster funds are proposed as the main policy tool [35]. However, this advice may be difficult to implement in the Pacific Islands, which face frequent and sizable natural disasters and do not have enough savings in the fund. Thus, we analyze the effects of natural disasters on the fiscal rules.

There is no literature on fiscal rules for the Pacific Islands. There is a positive relationship between economic growth and external debt, using a panel cointegration method for six Pacific island countries [36]. However, as far as we know, very little attention has been paid in the literature to fiscal rules for the Pacific Islands. This may be partly because only limited information and data are available for these countries. Thus, we examine fiscal rules customized for the Pacific Islands, which can be applicable to other small states in the Caribbean or Africa.

\subsection{Fiscal Rules and Targets in the Pacific Islands}

Pacific islands have various fiscal rules or targets (Table 1). Fiji has a $40 \%$ debt-to-GDP ratio as an indicative ceiling. Palau has a non-negative budget balance rule. Some countries have a combination of debt and budget balance rules. Solomon Islands has a public debt limit of 30\% of GDP and a budget balance rule in which recurrent spending should be financed by revenue (not by debt; golden rule). The golden rule improves welfare when the growth enhancing effect of new resources available for productive public spending exceeds the crowding-out effect of the debt burden arising from deficit on future economic growth [37]. A golden rule exempting net public investment from the balanced-budget requirement allows for welfare gains to both current and future generations [38]. The downside of the golden rule is that it reduces the comprehensiveness of the budget balance target and, in turn, weakens its link with the objective of debt sustainability [39]. Samoa has both debt (50\% of GDP excluding contingent liabilities) and fiscal deficit limit of $2 \%$ of GDP, while Vanuatu has $40 \%$ anchor of the present value of government debt-to-GDP ratio and ex ante recurrent budget balance rule. Tonga has several fiscal rules and targets: external public debt ceiling of $50 \%$ of GDP; compensation for employees should be below $53 \%$ of domestic revenue and $45 \%$ of operating expense; minimum revenue target of $22 \%$ of GDP; and cash buffers equivalent to three months of recurrent spending. Cook Islands has four fiscal rules: net debt of 30\% of GDP as a soft cap and 35\% as a hard cap; the fiscal balance cannot exceed a deficit of $1.9 \%$ of GDP; budgeted expenditure cannot grow by more than $4 \%$ year-on-year; and the equivalent of three months of operating expenditure must be held in cash reserves at any one time. In addition to these fiscal rules, Cook Islands also has operational guides, such as personnel emolument ratio - expenditure on personnel less than $40 \%$ of total government revenue. Similarly, PNG also has multiple fiscal rules and targets. First, PNG has a debt target that aims to limit gross central government debt-to-GDP ratio within a range of 30-35\% of GDP. Second, PNG also has a zero average non-resource primary balance target over the medium term. Furthermore, PNG has an expenditure rule that limits personnel emolument costs below $40 \%$ of non-resource and non-grant revenue. Given the size of the economy and its diversified economic structure encompassing all characteristics of the Pacific Islands (i.e., commodity exporters, reliance on grants, frequent natural disasters, and climatic shocks) as well as data availability, we choose PNG as an example of a Pacific island country in our analysis of fiscal rules. 


\subsection{Research Question}

Small states governments are looking for a new fiscal framework to address challenges caused by natural disasters and climate change. Given the review of literature above and fragile small states' challenging practice explained in the introduction, we answer the following research question. How should small states formulate a countercyclical fiscal policy to achieve economic stability and fiscal sustainability when prone to natural disasters, climate change, commodity price changes, and uncertain donor grants? Traditionally, natural disaster funds are recommended as the main policy tool to deal with natural disasters and the second-generation fiscal rules supports escape clauses for natural disasters or other large shocks [40]. Detailed discussions on generational fiscal rules are made in Section 5 of this paper. However, this policy mix does not work in the small states highly vulnerable to natural disasters for the following two reasons. First, they do not have sufficient resources to save in disaster funds, given the limited fiscal space in practice. Second, if all natural disasters are put in escape clauses, then there is almost no fiscal policy advice for the Pacific Islands that face massive natural disasters every year and do not have enough savings in the fund. Therefore, the most interesting part of our study is to develop the first-ever cutting-edge rule-based fiscal policy framework that can address practical challenges in the small states prone to natural disasters. We provide a summary of our research methodology in the next section.

\section{Methodological Approach}

An objective of this article is to study the fiscal policy rules and fiscal targets incorporating natural disasters and climate change both theoretically and empirically. A main methodology adopted in this paper to analyze the short-run and long-run effects of natural disaster shocks on fiscal policy is to investigate their effects on public debt dynamics. This is because sustainability of fiscal policy ultimately depends on debt sustainability.

In the next analytical section, we study debt sustainability of the Pacific Islands from the normative and positive perspectives. The Pacific Islands are chosen for the sample of our study on small states because they are most vulnerable to natural disasters and climate change. Specifically, we first estimate the fiscal reaction function of the Pacific island economies using the available country panel data on nine Pacific island states from the IMF's World Economic Outlook Database. All available data from the Pacific island countries, during the period from 1990 to 2018, are included. Our unbalanced country panel data include Fiji, Kiribati, Marshall Islands, Micronesia, PNG, Solomon Islands, Timor-Leste, Tuvalu, and Vanuatu. Data for Nauru, Palau, Samoa, and Tonga are not available. We show that there is a slightly nonlinear relationship between the primary balance and public debt in the Pacific Islands.

In the subsequent section, we study the effects of natural disaster and climate change on debt sustainability and debt target using the theoretical model, starting from the government's cash-flow constraint. It is important to understand the theoretical impact of such shocks on debt sustainability because as we will elaborate later, there is no conclusive empirical evidence so far in the extant literature. Therefore, our normative analysis is one of our main contributions to the literature on fiscal rules and economics of natural disasters. We also link the debt target to expenditure rules, showing that the recurrent expenditure rule is the most practically useful for small states vulnerable to natural disasters and climate change. Throughout the analysis, we use the parameters for the PNG economy as an illustrative example of the Pacific Island to demonstrate practical guidance for policy-makers. We chose PNG because it is the largest economy in the Pacific Islands, it has all characteristics of the region (commodity exporters, reliance on grants, frequent natural disasters, and climatic shocks), and we have available data for our analysis.

\section{Analysis of Fiscal Rules and Targets}

We analyze five different fiscal rules and targets against natural disasters. We discuss debt, budget balance, expenditure, revenue, and cash buffer rules and targets. Note that 
fiscal targets are objectives to be achieved by the fiscal policy, while fiscal rules are the means or constraints to achieve the targets. Beginning with a debt target, we first discuss how natural disasters and climate change affect debt dynamics. We should distinguish between temporary shocks - natural disasters-which do not change the steady state, and permanent shocks - climate change-which do. Then, we study the implications of debt for budget balance. Next, we propose expenditure rules and their relationship with revenue structure and disaster funds.

\subsection{Long-Run Debt Target}

First, we discuss debt targets. We show two approaches for debt targets: an empirical approach and a normative approach. We start our discussion with the empirical approach

We use country panel data on Pacific Islands to find the debt-to-GDP ratio that maximizes the primary balance. There is a nonlinear relationship between the primary balance and debt ratio if the fiscal reaction function is assumed (Figure 2). An economic intuition is that a government displays fiscal fatigue, whereby its ability to increase primary balances cannot keep pace with rising debt [41]. Thus, fiscal fatigue, observed in the empirical literature, is the loss of capacity or intention by the government to control debt accumulation using its primary balance consolidation despite the debt ratio exceeds an unsustainable level [42]. As shown in Figure 2, the fiscal authority tends to respond nonlinearly to the debt level. For example, Vanuatu loosened fiscal policy in 2015, widening primary deficit by $3.7 \%$ of GDP despite the sharp increase in public debt-to-GDP ratio from $24.8 \%$ of GDP in 2014 to $34.7 \%$ in 2015 . This was driven by the fiscal authorities' intention for an ambitious infrastructure investment program. This action posed threats to debt and fiscal sustainability, raising the country's debt distress rating, and it demonstrated the need for careful selection of projects and reprioritization of expenditure as well as revenue mobilization efforts to bring down the debt ratio on a declining path. In such nonlinear relationship between primary balance and debt level, the fiscal reaction function can be defined as follows.

$$
p b_{i, t}=\varnothing+\alpha_{1} p b_{i, t-1}+\beta_{1} d_{i, t-1}+\beta_{2}\left(d_{i, t-1}\right)^{2}+\epsilon_{i, t}
$$

where $p b_{i, t}$ is the primary balance, $\varnothing$ captures all systematic determinants of the primary balance other than lagged debt, $\beta$ are estimated coefficients on lagged debt level $d_{i, t-1}$ $\left(\beta_{1}>0, \beta_{2}<0\right)$, and $\epsilon_{i, t}$ is an independent and identically distributed shock to the primary balance. In this case, multiple equilibria emerge to determine the debt level as Figure 2 shows. Note that interest payments are assumed to increase nonlinearly as the debt level goes up. In this setting, the debt limit becomes $\bar{d}$.

If there is a certain point of debt-to-GDP ratio that improves the primary deficit, fiscal sustainability is satisfied. In this context, we plot the Pacific island countries' data on primary balances and gross public debt-to-GDP ratios sourced from the IMF's World Economic Outlook Database. As explained in the previous methodological approach section (Section 3), all available data from the Pacific island countries are included. The descriptive statistics are shown in Table 2 and regression results are presented in Table 3. The regression equation is (1). Note that our intention here is to show some evidence of nonlinear relationship between debt and primary balance, and maximizing the primary balance is not a goal of fiscal policy.

Table 2. Descriptive statistics.

\begin{tabular}{cccccc}
\hline Variable & Mean & Median & Std. Dev. & Min & Max \\
\hline Primary Balance & -0.961 & -0.333 & 10.548 & -39.522 & 47.537 \\
\hline Debt-to-GDP Ratio & 26.980 & 25.980 & 16.557 & 0.000 & 76.680 \\
\hline Terms of Trade & 94.861 & 96.650 & 5.670 & 74.120 & 107.870 \\
\hline
\end{tabular}




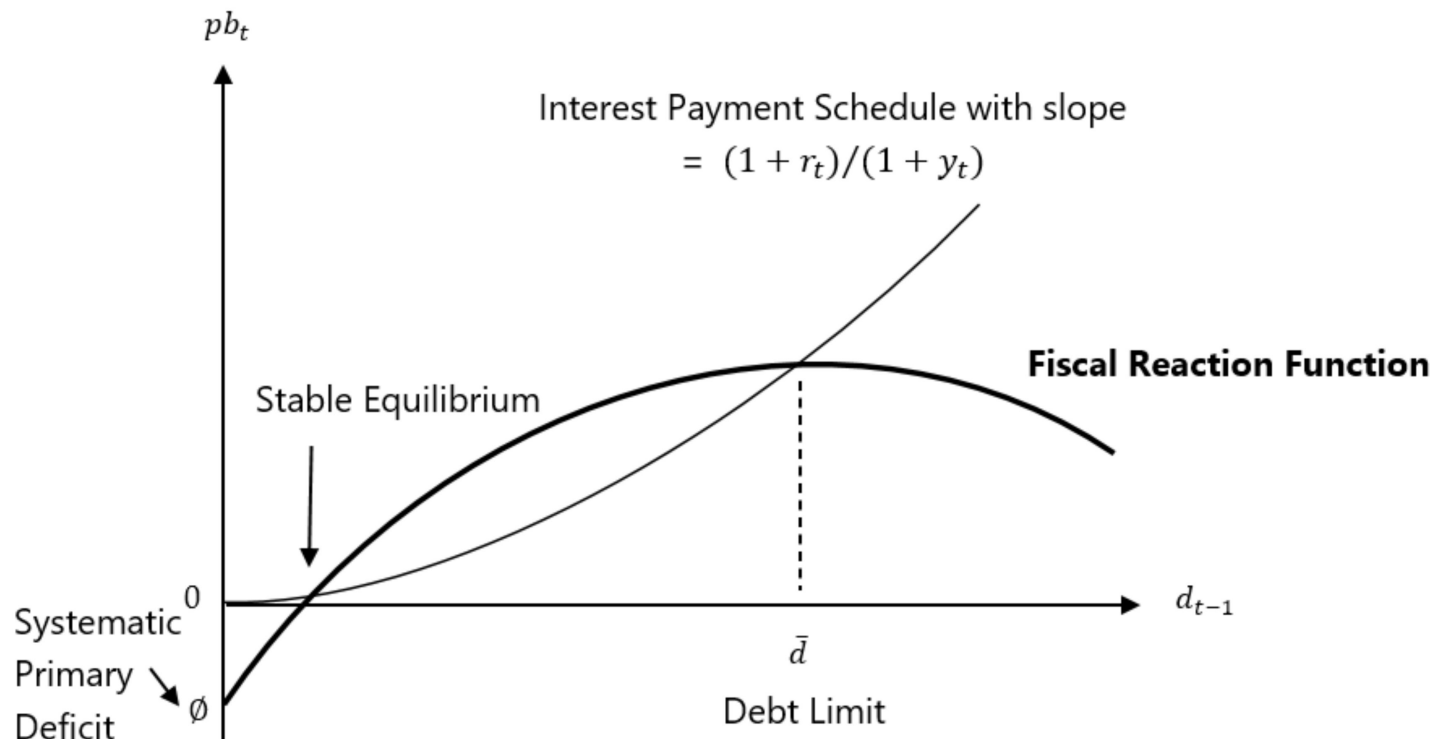

Figure 2. Debt ceiling with fiscal reaction function.

Table 3. Results of estimated fiscal reaction function for the Pacific Islands.

\begin{tabular}{ccc}
\hline Variable & Baseline Estimation & Robustness Check \\
\hline Primary Balance (PB)_t-1 & $0.6570^{* * *}$ & $0.6485^{* * *}$ \\
& $(0.0573)$ & $-0.0655)$ \\
\hline [Debt-to-GDP Ratio] $\times$ [Debt-to-GDP Ratio] & $-0.0056^{* * *}$ & $(0.0027)$ \\
\hline Debt-to-GDP Ratio & $(0.0024)$ & $0.2941^{* *}$ \\
\hline Terms of Trade & $0.3108^{* *}$ & $(0.1560)$ \\
\hline Constant & $(0.1365)$ & 0.0426 \\
\hline Implied PB Maximizing Debt-to-GDP Ratio & & $(0.1256)$ \\
\hline Corresponding PB & -2.9033 & -7.1370 \\
\hline R-squared & $(1.7842)$ & $(12.3257)$ \\
\hline F-statistic & 27.611 & 28.755 \\
\hline Observations & 1.388 & 1.004 \\
\hline
\end{tabular}

Note: The dependent variable is primary balance. Standard errors are in parentheses. Statistically significant at the 1 percent level $\left.{ }^{* * *}\right)$, at the 5 percent level $\left({ }^{* *}\right)$, and at the 10 percent level $\left({ }^{*}\right)$.

Our baseline estimation results in the first column of Table 3 shows both quadratic and linear terms of debt-to-GDP ratio are statistically significant at the $5 \%$ level. Note that we include the lagged dependent variable as a regressor in our estimation because the literature often finds that the primary balance is autocorrelated. We find that the primary balance is maximized at a $28 \%$ debt-to-GDP ratio in the Pacific Islands. Figure 3 shows the relationship between the public debt-to-GDP ratio and primary balance as a percentage of GDP. There is a slightly nonlinear relationship between these two variables, as the fiscal reaction theory predicts. An economic intuition behind this is that countries can benefit from debt financing by increasing investment and enlarging the economic base with low debt, but the costs of repaying debt increase as the debt reaches a critical level. For robustness checks, we also include a commodity terms of trade index published by the IMF as an independent variable since the literature suggests that low-income countries 
are dependent on terms-of-trade fluctuations. Our robustness check in the second column of Table 3 indicates that the statistical significance of estimated coefficients, R-squared, and F-statistic become lower than the baseline, partly due to the reduced sample size. Since we have very limited sample size for available data on small states in the Pacific, it is very difficult to conduct robust econometric analysis as we increase the number of explanatory variables. Again, the estimated primary balance maximizing debt-to-GDP ratio is around $28 \%$. Therefore, we conclude that the primary balance maximizing debt-toGDP ratio is slightly lower than the $30 \%$ in the Pacific island countries, which lies at the lower bound of the case for other emerging market economies explained in the literature review section (Section 2). This result is not surprising if we consider the small economic base and the nature of small insular economy, which is vulnerable to natural disasters and climate change.

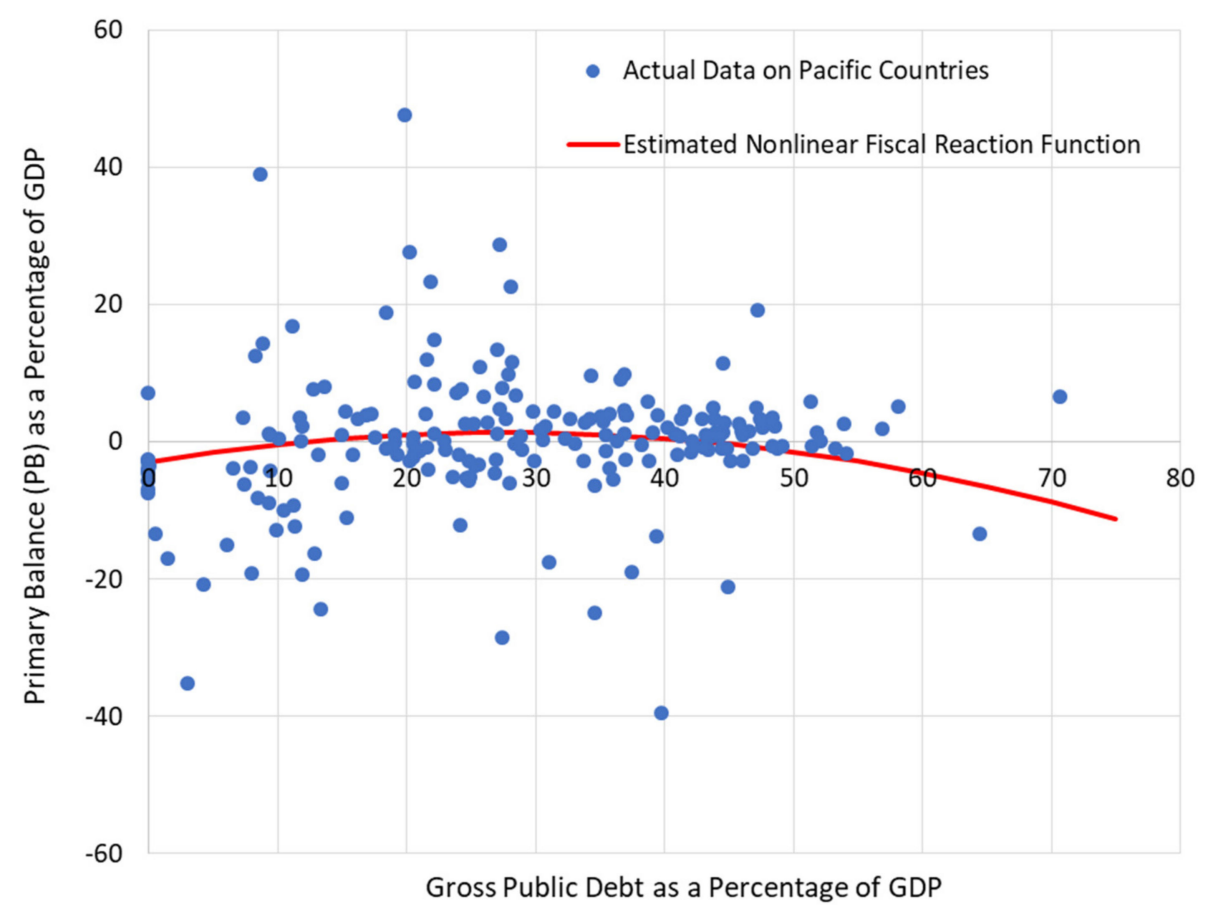

Figure 3. Fiscal reaction function in the Pacific Islands. Source: IMF World Economic Outlook Database, October 2019 [43].

Next, fiscal rules for small islands are discussed from a normative perspective, incorporating a natural disaster shock into the debt sustainability framework. We examine public debt dynamics, starting from the government's cash-flow constraint:

$$
T_{t}+G_{t}+O_{t}+D_{t}+\Delta M_{t}=E_{t}+K_{t}+\left(1+i_{t}\right) D_{t-1}+S_{t} N_{t}
$$

where $T_{t}$ is tax revenue; $G_{t}$ is grants from donor countries; $O_{t}$ is other revenue including dividends from state mineral companies; $D_{t}$ is government debt; $\Delta M_{t}=M_{t}-M_{t-1}$ is money issuance (fiscal deficit can be financed by the central bank); $E_{t}$ is government recurrent expenditure defined as expense, which is expenditure excluding net acquisition of non-financial assets, minus interest (i.e., recurrent expenditure is calculated as a sum of compensation of employees, use of goods and services, grants, social benefits, and other expenses); $K_{t}$ is capital expenditure (i.e., public investment); $\left(1+i_{t}\right) D_{t-1}$ is the repayment of debt issued in the previous period; $S_{t}$ is the share of the net fiscal cost of shock that is picked up by the government; and $N_{t}$ is the GDP impact of the shock such as a natural disaster. It is to be noted that $S_{t} N_{t}$ is the net effect of a disaster shock on the budget balance for analytical convenience, that is, the effect of spending minus revenue. In other words, each component of revenue and expenditure without a natural disaster is expressed in 
items before this cross-term $\left(S_{t} N_{t}\right)$ in Equation (2). This framework can be also applied to other types of shock, namely the terms-of-trade shock.

To get a sense of composition of natural disasters' impacts on budget and financing needs, the episode of Fiji's cyclone Evan in 2012 provides a good example [44]. According to the Fijian government, the recovery, reconstruction, and disaster risk reduction needs associated with the cyclone were 77 million Fijian dollars (F\$). Extra a half million F\$ was collected from public donations, and $\mathrm{F} \$ 1$ million was allocated from the prime minister fund. Besides that, there was F\$7 million reallocated from the national budget, whilst F\$9 million was received from development partners, international organizations, local nongovernment organizations, businesses and individuals as cash grants and aid-in-kind.

Equation (2) can be rewritten by dividing it into resource and non-resource revenues. Resource revenue is the sum of taxes and other revenues from the resource sector $\left(R_{t}^{\text {resource }}=T_{t}^{\text {resource }}+\mathrm{O}_{t}^{\text {resource }}\right)$. In contrast, non-resource revenue is the rest of government revenue $\left(R_{t}^{\text {non-resource }}=T_{t}^{\text {non-resource }}+O_{t}^{\text {non-resource }}+G_{t}+\Delta M_{t}\right)$. Stable revenue is the sum of taxes and other revenues from the non-resource sector $\left(R_{t}^{\text {stable }}=T_{t}^{\text {non-resource }}+O_{t}^{\text {non-resource }}\right)$. In many Pacific island countries, donor grants $G_{t}$ are an important source of budget funding. In the case of commodity exporters, mineral taxes in $T_{t}^{\text {resource }}$ and mining and gas dividends in $O_{t}^{\text {resource }}$ are also important revenue sources.

$T_{t}^{\text {resource }}+O_{t}^{\text {resource }}+T_{t}^{\text {non-resource }}+O_{t}^{\text {non-resource }}+G_{t}+\Delta M_{t}+D_{t}=E_{t}+K_{t}+\left(1+i_{t}\right) D_{t-1}+S_{t} N_{t}$

If we divide Equation (2) by nominal GDP $P_{t}=P_{t} Y_{t}$, where $Y_{t}$ is real GDP and $P_{t}$ is the GDP deflator, all the variables can be expressed as shares of GDP in lower-case letters:

$$
t_{t}+g_{t}+o_{t}+d_{t}+\mu_{t}=e_{t}+k_{t}+\left(1+i_{t}\right) /\left\{\left(1+y_{t}\right)\left(1+\pi_{t}\right)\right\} d_{t-1}+s_{t} n_{t}
$$

where $y_{t}=Y_{t} / Y_{t-1}-1$ is the real growth rate of output and $\pi_{t}=P_{t} / P_{t-1}-1$ is the inflation rate (for GDP deflator). To simplify the notations, the real interest rate is denoted by $1+r_{t} \equiv\left(1+i_{t}\right) /\left(1+\pi_{t}\right)$ and the primary balance is expressed as $p b_{t}=t_{t}+g_{t}+o_{t}-$ $e_{t}-k_{t}$. Then, the budget constraint implies the following debt dynamics.

$$
d_{t}=\left(1+r_{t}\right) /\left(1+y_{t}\right) d_{t-1}-p b_{t}-\mu_{t}+s_{t} n_{t} .
$$

In the steady state where $d^{*} \equiv d_{t}=d_{t-1}$, Equation (5) becomes:

$$
d^{*}=(p b+\mu-s n) /\{(1+r) /(1+y)-1\} .
$$

The debt dynamics in Equation (5) are shown graphically in Figure 4, for the case where the real interest rate is higher than the growth rate. This is a case when debt could diverge from the steady-state value $d^{*}$. Note that we do not analyze the case where the real interest rate is lower than the growth rate because in this case the debt dynamics automatically converges toward the stable steady-state debt level over time and hence there is no need for fiscal policy rule. Thus, it is crucial to have the debt level below the steady-state value to keep debt sustainable. We do not worry about the case where the debt diverges toward zero because it is unrealistic. sn represents the long-term historic average of the impact of disasters. This approach is a straightforward way to include the effects of natural disasters when considering debt sustainability in the long term. An economic intuition is that the amount $s n /\{(1+r) /(1+y)-1\}$ can be understood as a debt buffer against natural disasters. Note that steady-state parameters can be affected by the governmental activity. For instance, the government can choose the primary balance $(p b)$ in the steady state to change the steady-state debt level $\left(d^{*}\right)$. In this sense, we can think of the primary balance as a choice variable for the government. Another approach to calibrate the debt target is by doing stochastic simulations (via e.g., VAR) to know the debt threshold over which the debt becomes unsustainable. However, due to limited availability of economic data in the Pacific island countries, this approach is not practically useful. 


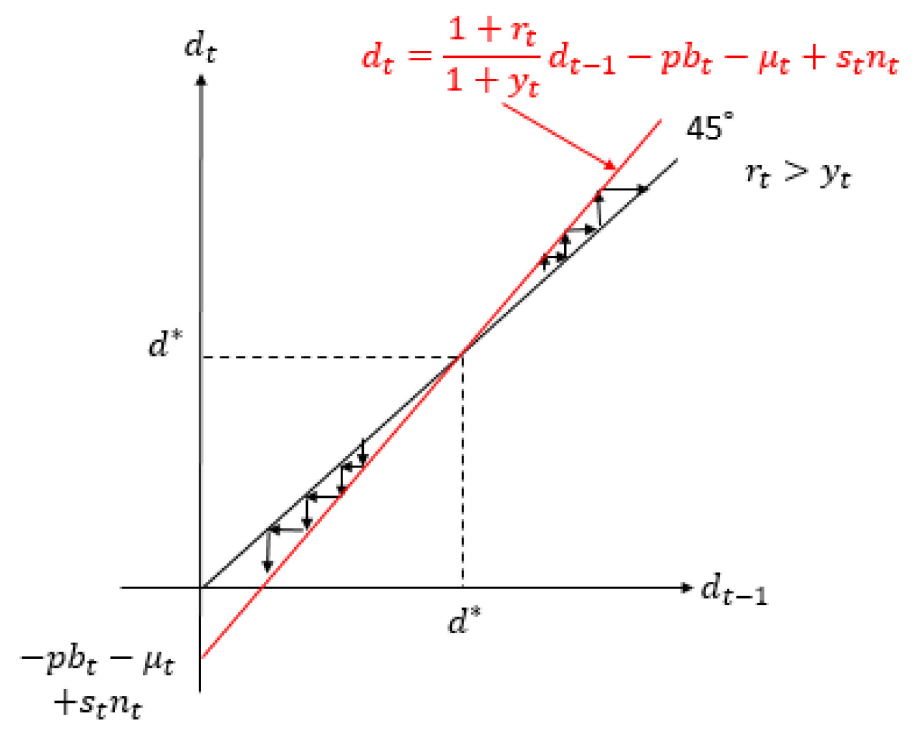

Figure 4. Debt dynamics with natural disaster shocks.

In our example of PNG, simple calculation indicates that the steady-state debt level is around $30 \%$. In this exercise, the following steady-state values are assumed: a $0.4 \%$ of GDP primary budget surplus $(p b=0.004)$; a money creation rate of $0 \%$ (i.e., no central bank financing for budget deficit; $\mu=0)$; a real interest rate of $4.5 \%(r=0.045)$; a real potential growth rate of $3.8 \%(y=0.038)$; and an expected natural disaster shock per year of $0.2 \%$ of GDP $(n=0.002, s=1)$, as calculated by [45]. The magnitude of disaster shocks should be the effect on budget balance $\left(s_{t} n_{t}\right)$. However, it is not easy to estimate it in the Pacific islands because of limited information. The 0.2 percent shock used here is the effect on GDP assuming that the government can offset the adverse impact on the economy in the steady state $(s=1)$. This is the lower bound of the impact of extreme weather events on budget balance, as the fiscal impact ranges between 0.2 and 1.4 percent of GDP [46]. These values are chosen by taking into account various long-term factors and assumptions so that they are consistent with the IMF's debt sustainability analysis and macro framework at the end of the projection period. For example, when we make an assumption about the real interest rate, it is calculated as the nominal interest rate minus the inflation rate. The nominal interest rate assumption reflects the trend and level of interest rate before the country experienced large negative commodity price shocks in 2014 and, thereafter, fiscal crunch and foreign exchange shortages. As explained in introduction, the PNG economy has been hit by various shocks, so the actual negative primary balance and other economic variables in recent years should not be perceived as long-term steady state values. Please note that these parameters are the long-run steady-state values of growth rate and real interest rate, so they are not affected by the countercyclical fiscal policy. However, a drawback of this steady-state analysis is that the result can be sensitive to parameters, and it is not easy to know true steady-state values. Thus, the exercise presented in this paper should be treated as an illustration rather than true values for PNG.

We also analyze the effects of permanent natural disasters or climate change shocks on debt dynamics because the ex-ante optimal fiscal rule is no longer sequentially optimal in the presence of persistent shocks [47]. We analyze two cases because the impact of disasters on economic growth and the risk premium is ambiguous. The existing literature finds that the effects of natural disasters on economic growth can be either negative or positive $[48,49]$. Although it is likely that climate change or natural disasters affect economic growth negatively in the long term, some empirical studies found positive effects. For example, climate disasters are positively correlated with long-run economic growth rates and higher total factor productivity [50]. Moderate disasters (such as moderate flooding) can have a positive impact on medium- and long-term economic growth [51]. Floods have positive effects on agriculture through benefiting land productivity [52]. Catastrophic 
natural disasters do not have a significant effect on economic growth in either the short or long term [53]. By contrast, very large earthquakes and some meteorological disasters negatively affect the growth rate of real GDP per capita [54]. Natural disasters can also affect country risk premiums. Geophysical and meteorological disasters (e.g., earthquakes, tsunamis, volcanic eruptions, and storms) increase the sovereign risk premium, whereas hydrological and climatic disasters (e.g., flood, droughts, and wildfires) do not affect the premium in the long term [55]. Therefore, the effects of natural disasters on growth and interest rates in the steady state are somewhat ambiguous in general. However, it is likely that natural disasters have adverse growth impacts on low-income countries like Pacific Islands, given their limited reconstruction capacity in the aftermath of disasters.

The first case considered is an unexpected permanent natural disaster shock or climate change shock that increases long-term economic growth. For example, imagine the case where a massive earthquake occurs unexpectedly in the rural areas of PNG and one-way wooden bridges with gates are replaced by two-way steel bridges without gates. Then, better-quality infrastructure helps agricultural workers to transport a higher number of coffee bags for export. We can interpret this as a case in which economic disruptions caused by natural disasters trigger positive technological shocks during the recovery process. In such a case, the steady-state debt level could be higher than before the shock because of the improved long-run economic growth, as shown in Figure 5 (left). Note that this oversimplifies and overestimates the impact because we are comparing to a case in which the poor-quality infrastructure is never replaced. In reality, it would eventually be replaced, so that the disaster only brings the replacement date forward. Essentially, we are treating a temporary total factor productivity shock (which could be quite long) as permanent.

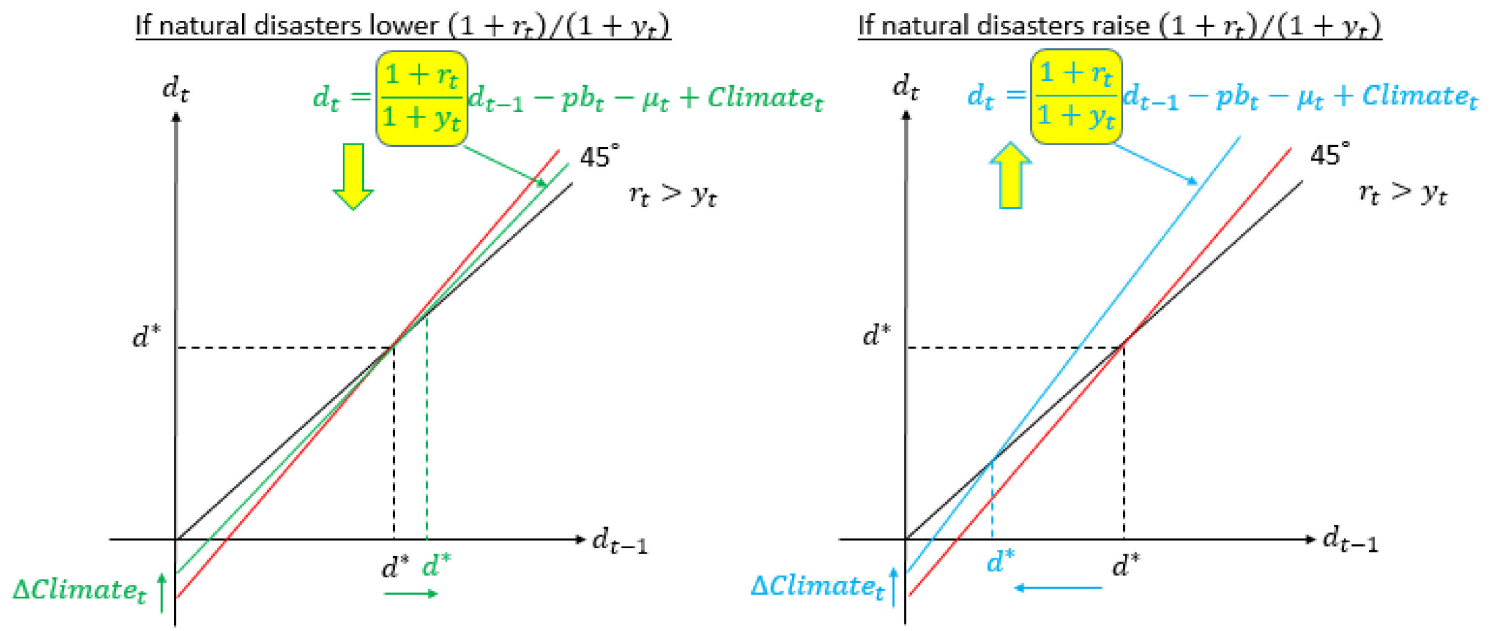

Figure 5. Impact of unexpected permanent natural disasters/climate change shocks.

By contrast, let us consider the second case, in which climate change dampens economic activity permanently. For example, if global warming causes the sea levels to rise in the Pacific Ocean, climate change shocks increase the probability and severity of natural disasters as atoll nations (such as Tuvalu and Kiribati) lose land for economic activities. This is a serious concern for the northern islands in the South Pacific region, and it corresponds to the case shown in Figure 5 (right). In this case, the steady-state debt level should be lower than earlier because of lower economic growth relative to the interest rate in the steady state. This exercise implies that, if an unexpected permanent shift in the probability of natural disasters is observed, the debt target should be reconsidered or revised.

Note that this argument can be also applied if the government changes the preference of covering the disaster loss. In other words, a shock to variable "Climate $e_{t}=s_{t} n_{t}$ " does not have to be more destructive or more frequent disasters, but it could come from the government covering a larger share of the cost $\left(s_{t}\right)$ of a natural disaster shock to the GDP. 
When choosing the value of share $\left(s_{t}\right)$, the government needs to consider the disaster recovery efforts made by the private sector and the local communities. This could also be relevant to terms-of-trade shocks if the government tax or subsidy policy provides better for the private sector.

\subsection{Budget Balance Target}

We have thus far analyzed how to adjust the debt target to include the effects of natural disasters. The next step is to derive a budget balance target. Small states typically have no well-defined economic cycles, which make it difficult to define the structural budget balance. Even if we can calculate the structural budget balance by using some filtering techniques, it is well known that the structural balance is very sensitive to calculation methods. In practice, cyclically-adjusted budget balance is less reliable when they are needed most (i.e., under conditions of poor or deteriorating public finances) [56]. Additional complexities of defining the business cycle arise in the case of a resource-rich economy, such as PNG or Solomon Islands. Given these technical problems, we recommend using the headline budget balance as an anchor when formulating budget balance targets in the Pacific Islands.

How can we derive the budget balance target from the debt target? Here we focus on the overall budget balance rather than the primary balance for analytical simplicity. Since the change in debt $\left(\Delta D_{t}\right)$ equals the budget deficit $\left(-B_{t}\right)$, the debt equation can be written as:

$$
D_{t}=D_{t-1}+\Delta D_{t} ; \Delta D_{t}=-B_{t}
$$

where $B_{t}=T_{t}+G_{t}+O_{t}+\Delta M_{t}-E_{t}-K_{t}-i_{t} D_{t-1}-S_{t}$ is the budget balance. Dividing this equation by nominal GDP with nominal growth rate $\gamma_{t}$, the debt equation can be expressed as a share of GDP.

$$
d_{t}=d_{t-1} /\left(1+\gamma_{t}\right)-b_{t}
$$

In the steady state, the budget balance as a percentage of GDP is given by

$$
b^{*}=-\gamma /(1+\gamma) d^{*}
$$

For PNG, the implied budget deficit target is $1.4 \%$ of GDP. Nominal GDP growth is assumed to be $5 \%$ in PNG $(\gamma=0.05)$. Although the historical average of nominal GDP growth rate in PNG is higher, we exclude the impact of construction of massive LNG facility, which happened in recent years, when we calibrate the steady-state nominal growth rate. Given the $30 \%$ debt target derived above $\left(d^{*}=0.3\right)$, budget deficit in the steady state is calculated as $1.4 \%$ of GDP in PNG $\left(b^{*}=-0.014\right)$. Bear in mind that we are talking about the long-run steady-state value of growth rate, which is not affected by the countercyclical fiscal policy. Again, please note that this value is presented as an illustration rather than the recommended value.

If the actual budget balance $b_{t}$ deviates from the target $b^{*}$ in practice, the fiscal authority can decide the adjustment period with a time span of $\lambda$ years. If the country has more fiscal space, the length of adjustment span can be shorter. This is because that sticking with a fixed budget deficit target implies that the impact of shocks moving the debt/GDP ratio away from target will only be eliminated asymptotically. The fiscal adjustment (or budget balance rule as a correction mechanism of deviation from the target) to achieve the target each year during the adjustment period (from year $t+1$ until year $t+\lambda$ ) is as follows.

$$
\left(b_{t}-b^{*}\right) / \lambda, \forall b_{t} \neq b^{*} .
$$

Equation (10) is a simple linear budget balance adjustment rule. Depending on the preference of the fiscal authorities, other nonlinear adjustment rules are also possible. 


\subsection{Expenditure Rules}

It is more important to have an expenditure rule than a revenue rule to reduce the procyclicality of the economy. This is because some countercyclical fiscal policies are already embedded in government revenues. For example, if the economy is experiencing a downturn, profits of corporations and incomes of households decline; therefore, the base for direct taxation shrinks. Sales of goods and services shrink, and indirect tax revenues such as value added tax also decrease. In this respect, automatic stabilizer effects prevail as the tax burden decreases during the phase of economic contraction. The opposite effects occur during economic expansion. By contrast, in general, government expenditure does not have the tendency to reduce procyclicality in the Pacific small states.

An expenditure rule can be derived from the budget balance target or rule, assuming a revenue target. If we assume a $14.8 \%$ revenue-to-GDP target ratio, consistent with PNG's Medium-Term Fiscal Strategy 2018-2022, with 5\% nominal GDP growth, the budget balance target can be interpreted as: (1) a constant $16.2 \%$ of expenditure-to-GDP ratio $(=14.8 \%$ revenue target $+1.4 \%$ deficit target); or (2) a ceiling of $5 \%$ nominal expenditure growth if PNG is already in an expenditure position consistent with the budget balance target.

For PNG, an expenditure rule related to non-volatile revenue has advantages in terms of volatility and cyclical stability, operational simplicity, and ease of understanding. Our example above has so far defined expenditure rules as a percentage of GDP for simple analytic purposes. However, GDP is more volatile than revenue in most Pacific island countries (Table 4 calculates the volatility of levels of variables). In such circumstances, defining expenditure rules as a percentage of GDP may add procyclicality to economic performance. In fact, the normalized volatilities in the last two columns of Table 4 show that nine of the thirteen countries would exhibit higher volatility if an expenditure rule were defined as a percentage of GDP rather than revenue. Another argument for reducing cyclicality of GDP is to use potential GDP like the EU, but the Pacific island countries do not have long GDP series time wise, and the presence of frequent natural disasters make it technically difficult to estimate potential GDP.

Table 4. Volatility of GDP, revenue, and expenditure in the Pacific Island countries. Most Volatile Item, Second Most Volatile Item, _ More Volatile Ratio).

\begin{tabular}{cccccc}
\hline Country & GDP & Revenue & Expenditure & Expenditure/GDP & Expenditure/Revenue \\
\hline Unit & \multicolumn{2}{c}{ Standard Deviation (SD) } & & SD Divided by Average for Standardization \\
\hline Papua New Guinea & 21.5 & 4.03 & 4.89 & 0.12 & 0.15 \\
\hline Fiji & 2.70 & 0.74 & 0.85 & 0.09 & 0.08 \\
\hline Timor-Leste & 1.81 & 0.33 & 0.54 & 0.63 & 0.24 \\
\hline Solomon Islands & 3.34 & 1.68 & 1.66 & 0.37 & 0.13 \\
\hline Vanuatu & 23.8 & 8.48 & 8.66 & 0.10 \\
\hline Samoa & 0.58 & 0.20 & 0.21 & 0.19 & 0.10 \\
\hline Tonga & 0.23 & 0.12 & 0.12 & 0.28 & 0.10 \\
\hline Micronesia & 0.05 & 0.05 & 0.03 & 0.09 & 0.16 \\
\hline Palau & 0.05 & 0.02 & 0.01 & 0.13 & 0.11 \\
\hline Marshall Islands & 0.03 & 0.02 & 0.02 & 0.13 & 0.16 \\
\hline Kiribati & 0.06 & 0.10 & 0.08 & 0.27 & 0.11 \\
\hline Nauru & 0.03 & 0.06 & 0.05 & 0.18 & 0.21 \\
\hline Tuvalu & 0.01 & 0.02 & 0.02 & & \\
\hline
\end{tabular}

Source: IMF World Economic Outlook Database, October 2019 [43].

Thus, expenditure rules defined as a percentage of stable revenue (non-resource, nongrant revenue) is preferable, for several reasons. First, a release of GDP data takes longer than estimation of revenue, and the impact of GDP revision is relatively large in the Pacific island countries. This is quite an important point in terms of operational feasibility. Second, since income tax revenues are based on the previous year's income of households and companies, expenditure rules based on revenue will be less volatile than if it is based on 
GDP, as it will not be affected by natural disaster shocks to GDP in the current year due to lags. Third, if the expenditure rule is defined as a percent of revenue, there is a direct link between expenditure and revenue. As a result, the level of overall balance is uniquely determined, and it will be easy to compute the level of spending irrespective of GDP. This is important for small fragile states because it is difficult to estimate the impact of natural disasters on GDP in a timely manner. All three reasons support the recommendation of revenue when formulating fiscal rules for the Pacific island economies.

Expenditure ceilings on certain spending categories (e.g., recurrent spending or personnel emoluments) may be useful in some circumstances. Ceiling on certain expenditure categories, particularly subject to pressure (e.g., wage bills, subsidies), may be considered. This is because the rule can give policy-makers clear operational guidance for enforcement. Operational guidance is a priority for countries with limited public financial management capacity. For instance, compensation for public employees has been an area of over-expenditure or under-budgeting in PNG during the past few years, and personnel costs have more than doubled over the past five years, partly reflecting the new tuition fee free policy. To address this situation, the Medium-Term Fiscal Strategy introduced an expenditure ceiling to cap personnel emolument costs below $40 \%$ of non-resource, non-grant revenue as shown in Equation (11). Using non-resource, non-grant revenue (stable revenue) as a base is a good strategy, as it can help avoid volatile resource revenue and uncertain grant elements, which have been a common fiscal concern in the Pacific Islands. It would be practical to exclude foreign grants in the revenue as foreign aid in the aftermath of massive natural disasters only covers $3 \%$ of total economic damages caused by the disasters [57]. There is no evidence that donors reallocate aid between recipient countries (cross-recipient reallocation) in the aftermath of large catastrophic natural disaster events [58]. In addition, there is usually a time lag until the foreign aid arrives in country aftermath of disasters, and foreign aid sometimes does not enter the budget. Designing an expenditure rule to cap personnel emolument costs could be also useful for other Pacific Islands as this category is typically the largest expenditure item, and some Pacific island countries (e.g., Kiribati and Vanuatu) have recently experienced a large increase in wages. In practice, fiscal space must be created if the country has already exceeded the limit by cutting unproductive spending.

$$
\text { (Personnel Emolument } t) / R_{t}^{\text {stable }} * 100<40 \%
$$

For the Pacific island countries, an investment-friendly expenditure rule, such as recurrent spending as a percentage of stable revenue, is a practically useful rule for stabilization purposes (Equation (12)). Put differently, the net acquisition of non-financial assets should be excluded from expenditure rule coverage since the government needs to rebuild infrastructure, such as coastal protection, in the event of natural disasters and there are still larger infrastructure requirements. In the Pacific, countries usually receive grants and loans from foreign governments or multilateral donors for reconstruction of infrastructure in the event of natural disasters. If public investment is financed by such grants, it will not affect the debt target. Note that public spending on risk reduction (e.g., infrastructure investment) needs to be consistent with fiscal space. In other words, given limited fiscal space in the small states, fiscal adjustment needs to be made in capital spending. Recurrent spending rules are more robust than personnel emolument rules because: (1) increases in use of goods and services are more serious concerns than personnel emoluments in some countries (e.g., Marshall Islands); (2) salaries of public employees may be included in grants to local government in some countries (e.g., Fiji); and (3) they avoid unintended effects of fiscal rules by shifting or evading fiscal burden into accounts unconstrained by the rules [59], thereby requiring less need for watchdog. In practice, to implement expenditure controls, public financial management systems need to be strengthened.

$$
E_{t} / R_{t}^{\text {stable }} * 100=X \%
$$


What kind of adjustment is required to satisfy a recurrent spending rule, given that all budget items are interconnected by the government's cash-flow constraint? Assuming that the economy is satisfying the steady-state budget balance target in Equation (9) before an actual disaster manifests as a shock, and using the government's cash-flow constraint (3), the recurrent expenditure rule (12) is given as:

$$
1+\left(R_{t}^{\text {resource }}+G_{t}+\Delta M_{t}-K_{t}-i_{t} D_{t-1}-S_{t} N_{t}-b^{*} P_{t} Y_{t}\right) / R_{t}^{\text {stable }}=X / 100
$$

Note that the budget balance target $b^{*}$ is a function of steady-state values of nominal and real GDP growth rates $(\gamma$ and $y)$, real interest rate $(r)$, primary balance $(p b)$, monetary financing $(\mu)$, and net fiscal cost of natural disasters $(s n)$. To understand more intuitively, Equation (13) can be rewritten as follows:

$$
(1-X / 100) R_{t}^{\text {stable }}+B_{t}^{\text {non-resource, non-recurrent }}-B^{*}=S_{t} N_{t}-R_{t}^{\text {resource }}
$$

where $B_{t}^{\text {non-resource,non-recurrent }}=G_{t}+\Delta M_{t}-K_{t}-i_{t} D_{t-1}$ is the budget balance calculated as non-resource revenue excluding stable revenue minus non-recurrent expenditure; and $B^{*}$ is the budget balance target before scaling by GDP (i.e., $B^{*}=b^{*} P_{t} Y_{t}$ ). We call Equation (14) as "the natural disaster-resilient fiscal rule" since it combines the recurrent expenditure rule with debt and budget balance targets incorporating natural disaster shocks.

We can consider the left-hand side of Equation (14) as the policy variable and the righthand side as the exogenous shock that small island economies cannot change (although $S_{t}$ can be a choice variable). The economic intuition is that if there is any surprise in resource revenue or natural disaster shocks, the government can allow the non-resource, non-recurrent budget balance to deviate from the target under Constraint (14). This enables the government to adjust to volatile resource revenues and rebuild infrastructure in the event of natural disasters.

In the case of $X=100$, where all non-resource, non-grant revenue can be spent as recurrent expenditure, the coefficient on the stable revenue term becomes zero, and hence it disappears from Equation (14). Note that Equations (9) and (6) show that the budget balance target, $B^{*}$, is higher when the average fiscal cost of a disaster $(s n)$ is higher or nominal GDP growth rate $(\gamma)$ is lower. Thus, a country satisfies the non-resource, nonrecurrent budget balance constraint, which allows some deviation from the target if the actual natural disaster cost is higher or resource revenue is lower than expected. This result is because the recurrent spending rule or natural disaster-resilient fiscal rule also constrains other items in the budget due to the government's cash-flow constraint. Further calculation could yield the condition in which other items, mainly public investment, are automatically determined by the fiscal rule, depending on the realized value of natural disaster shocks, which is another essence of the natural disaster-resilient (recurrent expenditure) rule.

To illustrate the case of the 2018 earthquake in PNG, the natural disaster-resilient fiscal rule would have suggested a $0.4 \%$ of fiscal stimulus in 2018 at the margin. Let us assume that the impact of the earthquake that occurred in PNG in 2018 is around 3\% of GDP $\left(n_{2018}=0.03\right)$, and the government covers a half of the economic loss $\left(s_{2018}=0.5\right)$. Given that our calibrated budget balance target is $-1.4 \%$ of GDP $\left(b^{*}=-0.014\right)$, if we assume that resource-revenue is $0.5 \%$ of GDP and $X=100$, then Equation (14) shows that non-resource, non-recurrent budget balance needs to be smaller than $-0.4 \%$ of GDP in 2018 ( $\left.b_{2018}^{\text {non-resource,non-recurrent }}=-0.004\right)$. Using the nominal GDP number in the 2018 budget, this is equivalent to 320 million Kina. To simplify the story, let us postulate that non-resource, non-recurrent budget balance is mainly driven by public investment. Under this assumption, approximately 320 million Kina can be spent on public investment or emergency relief. This calibrated amount is close to the actual 450 million Kina emergency relief approved by the PNG government, although other items on the budget are precluded in this argument. 


\subsection{Relationship with Revenue Structure}

How different are the revenue structures among the Pacific island countries? We need to take note of different revenue structures because revenue appropriation strategy depends on specific characteristics of the economy. For example, the permanent income hypothesis is useful for commodity exporters, especially for countries that collect revenue from nonrenewable resources (PNG and Timor-Leste). In this case, the non-resource primary balance as a percentage of non-resource GDP can be an option as a fiscal target to smooth resource earnings and promote intergenerational equity. Consumption from resource revenue should be a fixed proportion of the nation's annuity provided by the natural resource wealth, and it should be consistent with the permanent income hypothesis [60]. Our calibration for PNG indicates that the non-resource primary balance should be close to zero $(-0.3 \%$ of non-resource GDP) to be consistent with the permanent income hypothesis. It is important to exclude volatile resource revenue from the fiscal rule to avoid procyclicality. The volatile resource revenues in the Pacific island countries are listed in Table 5.

Table 5. Volatile resource revenue items in the Pacific Island countries.

\begin{tabular}{cc}
\hline Country & Resource Revenue Items \\
\hline Fiji & Fishing License Fees \\
\hline Kiribati & Fishing License Fees \\
\hline Marshall Islands & Fishing License Fees \\
\hline Micronesia & Fishing License Fees \\
\hline Nauru & - \\
\hline Palau & Mining and Petroleum Taxes; Mining, \\
\hline Papua New Guinea & Petroleum and Gas Dividends \\
\hline Samoa & Logging Revenues; Fishing License Fees \\
\hline Solomon Islands & Petroleum Revenue \\
\hline Timor-Leste & Fishing License Fees \\
\hline Tonga & - \\
\hline Tuvalu & \\
\hline Vanuatu & \\
\hline
\end{tabular}

It would be useful to point out the risks associated with each type of economy's revenue structure below. For countries whose main industries are renewable resources, such as fishing (Kiribati, Micronesia, Marshall Islands, Nauru, and Tuvalu) and logging industries (Solomon Islands), license fees can be an important indicator. If the countries relying on fishing industries increase recurrent spending when fishing revenue is high, it will be difficult to sustain fiscal policies when climate change adversely affects fishing activity. However, for small island economies such as Kiribati, Marshall Islands, and Tuvalu, it may be difficult to exclude fishing revenue as a volatile component from the revenue base because fishing license fees are a major source of revenue as other revenues are small. For countries exporting services such as Fiji, Vanuatu, and Palau, tourism revenues such as airport tax or taxes from service industries are important. The question arising is how to deal with countries relying on remittances, such as Tonga and Samoa. It could be cyclically synchronized with Australia/New Zealand business cycles where emigrant workers from these countries live. Finally, it could be important to set the minimum revenue requirement like Tonga to secure adequate revenues for the fiscal policy. 


\subsection{Stabilization Fund/Cash Buffers}

Fiscal surpluses during good years should be put in a stabilization fund (or natural disaster fund). If an actual fiscal outcome is better than the situation defined by the fiscal rule (expenditure rule), the fiscal surplus should be saved in the fund. These surpluses are needed in non-disaster years to build up reserves in the fund for emergency relief in disaster years. Holding reserves in the stabilization fund is necessary to meet cash outflows, particularly as the country's borrowing ability is constrained. In practice, due to the increased frequency of natural disasters, the targets may be more difficult to achieve.

Pacific island countries can also build cash buffers against natural disasters. For example, Tonga has a cash buffer rule, which requires the government to hold cash deposits equivalent to three months of recurrent spending. Solomon Islands had a similar cash buffer rule when the country implemented an IMF program in recent years. The idea of holding such cash buffers is similar to the stabilization fund discussed above. The preemptive policy by building fiscal buffers in the contingency fund leads to lower public debt levels than the post-disaster reactive policy adopted in Vanuatu [61]. This type of buffer ensures quick and easy access to funds in the event of economic shocks or natural disasters to reinforce the objective of operational fiscal sustainability. Although the cash buffer rule is defined as holding of cash reserves equivalent to three months of operating expenditure in most cases, it is neither calibrated nor aligned with other fiscal anchors.

For commodity exporters, stabilization funds can be funded from resource revenue windfalls. For example, the organic law on sovereign wealth fund in PNG legislates that 50 percent of all mining and petroleum taxes, 60 percent of the proceeds of sale of mineral or petroleum assets, and 75 percent of all distributions from the state's mining or petroleum projects will be deposited in the stabilization fund.

\subsection{Escape Clauses}

Well-defined and predetermined escape clauses may help budget execution in the presence of unexpected massive natural disaster shocks. If the size of a natural disaster shock is too big to be covered by the stabilization fund, the escape clause should be applied. In this situation, the debt target and fiscal rules can be recalculated, as elaborated in Figure 5. The government may breach fiscal rules only in the event of an unexpected disaster or a severe economic shock, which should be clearly defined in the law beforehand. However, we should note that flexibility provisions (such as escape clauses) could complicate the budget process by allowing fiscal targets to change with circumstances. Since triggering an escape clause involves a costly review process in practice, it is generally optimal to have an escape clause if the cost of review is cheap, the volatility of shocks is high, and the government deficit bias is severe [62]. The existing literature reports mixed results on the impact of escape clauses on fiscal stance. For example, escape clauses in fiscal rules do not seem to affect the cyclical stance of fiscal policy and public spending [63]. In contrast, fiscal rules with escape clauses are harmful for stabilization in high-debt countries by making fiscal policy more procyclical [64]. Escape clauses reduce countercyclicality of fiscal policy in developing countries [65]. Thus, country authorities should be very careful when applying escape clauses to violate fiscal rules.

\subsection{Forward-Looking Mechanism}

A suggested approach to handle escape clauses is to have a forward-looking explanation mechanism similar to inflation targeting regimes in monetary policy. If unexpected and devastating natural disasters happen and trigger the escape clause, the fiscal authorities should provide the future fiscal path to explain how fiscal targets will be met over the medium term. This is similar to the inflation targeting approach adopted by central banks worldwide. Namely, if a drought causes inflation to deviate from the inflation target, the monetary authority needs to explain how this effect from climate change or natural disaster dissipates over time and type of policy action required to meet the inflation target in the medium term. The same forward-looking approach is useful for fiscal policy-making. In 
other words, the fiscal authority needs to analyze and explain how natural disasters affect revenues, expenditures, and debt projections in the medium term and what kind of fiscal consolidation plan is required to meet the target over time. This will increase the credibility of the fiscal policy.

\subsection{Procedural Issues}

Strong political leadership with good communication is needed for the government to adopt fiscal rules. Fiscal rules should be reviewed periodically because the assumptions on which they are based may be subject to change. However, the revision process should be made as non-political as possible to avoid damaging the credibility of the rules-based approach. Regular intervals for amendment should not be linked to the election cycle to keep the fiscal rules independent from changes in the government. Fiscal rules contribute to disciplined fiscal policy after a change in government [66]. Moreover, countries with established democracies tend to have a strong effect of fiscal rules [67]. Transparency of the process is extremely important. Designing fiscal rules that can be easily communicated has more significance.

Strong legal and institutional arrangements are also important to commit and implement fiscal rules. The recent literature points out the importance of independent monitoring or enforcement bodies for better compliance of rules. Covering larger parts of general government finance and independent enforcement bodies issuing real-time alerts significantly increases the likelihood of compliance with fiscal rules [68]. The presence of a fiscal council promotes greater compliance with fiscal rules [69]. A fiscal council could act as an enforcer and revise the rules [70]. It is recommended that proposals for fiscal rules be published for transparency purpose so that outsiders—such as academic professionals-can provide inputs as independent opinions.

\section{Discussion}

\subsection{Second-Generation Fiscal Rules}

How can we position our new natural disaster-resilient fiscal rule in the existing literature on fiscal rules? The recent trend in the fiscal rules is called second-generation fiscal rules [40]. Second-generation fiscal rules had three characteristics: simplicity, flexibility, and enforceability. First, they use simple rules such as nominal balance rules. Second, they are designed to be flexible by putting natural disasters and other large events in the escape clause. In addition, to attain countercyclical nature, sophisticated rules (e.g., cyclically-adjusted budget balance rule) are recommended. Countries with flexible fiscal rules do not show negative effects of fiscal consolidation on public investment [71]. Third, to promote enforceability of fiscal rules, fiscal council and broader sanctions are embedded.

However, the second-generation fiscal rules have many drawbacks for small developing states. First, they are operationally difficult because it is hard to estimate potential output or cyclically-adjusted budget balance in the small states due to lack of relevant data and presence of natural disasters. Second, escape clauses are useless in countries facing frequent natural disasters as they invalidate fiscal rules. Third, it takes long time to estimate the impacts of natural disaster or climatic shocks on the economy and we need fiscal rules that do not require such assessment. Fourth, given the limited institutional capacity, small developing states need fiscal rules that do not face an enforceability issue (e.g., requirement of fiscal council, sanctions, etc.) and do not need frequent revisions of the rules. The natural disaster-resilient fiscal rule that we propose in this article satisfies conditions to address all these issues as we elaborate in the next subsection.

\subsection{Third-Generation Fiscal Rules}

Our proposed new natural disaster-resilient fiscal rule (i.e., recurrent expenditure rule with the debt and budget targets with expected disaster shocks) is quite different from the second-generation rules for various aspects. 


\subsubsection{Feasibility}

First, in our fiscal framework, practical feasibility for small developing countries with very limited capacity is a top priority. Therefore, all variables in our natural disasterresilient rule (or recurrent expenditure rule) are taken from the government budget. Moreover, there is no need to estimate the structural budget balance, which is another comparative advantage of our recommended rules, because small states typically have no well-defined economic cycles, making it difficult to define the structural budget balance. Furthermore, there is no need to estimate potential GDP because it is no longer required for the natural disaster-resilient fiscal rule and the recurrent expenditure rule.

\subsubsection{Timeliness}

In addition, we do not need to wait the publication of GDP as our new fiscal rules are not expressed as a percentage of GDP. Our fiscal rules are also free from revision of GDP. Furthermore, there is no need for the fiscal authorities to estimate the impact of natural disasters on GDP. As Table 4 shows, GDP is much more volatile than government revenue in the Pacific Islands, and we cannot define fiscal rules as a percentage of GDP. Instead, our natural disaster-resilient fiscal rule is rather based on stable element of revenue. Thus, it is very timely to see the deviation from the rule because, as soon as the budget outcomes are published, the commitment to the rule is timely checked. In addition, fiscal policy can be formulated in line with the natural disaster-resilient fiscal rule at each budget cycle as all variables defining the rule are in the budget forecast.

\subsubsection{Countercyclicality}

One of the innovations in our fiscal rules is that countercyclicality of fiscal policy is generated from the fiscal variables without requiring information on GDP and economic cycles. Our fiscal rules do not require the cyclically-adjusted fiscal balance, but we still have countercyclical elements by both: (i) using non-resource, non-grant revenue in the denominator in the recurrent expenditure rule (and the natural disaster-resilient fiscal rule); and (ii) excluding capital spending component from the numerator. The former helps avoid effects from volatile resource revenue and uncertain grant elements, whereas the latter allows countercyclical fiscal stimulus in the event of natural disasters. Our rules focus on the expenditure side, which is supported by empirical evidence that expenditure rules are more favorable effects on primary balance [26]. Furthermore, our proposed fiscal rules are better than the balanced budget rule because we can avoid procyclical fiscal policy (procyclical revenue volatility transmits to expenditure volatility).

It is also worth noting that, in our natural disaster-resilient fiscal rule, the government can choose to cover how much of the total disaster impact by the public sector through determining $S_{t}$. Thus, this choice variable can be used for the countercyclical fiscal purpose as well.

\subsubsection{Completeness}

In addition, the recurrent expenditure rule and the natural disaster-resilient fiscal rule are better than existing personnel emolument rules in several Pacific Islands (Cook Islands, PNG, and Tonga) because they can avoid unintended effects of fiscal rules by shifting or evading fiscal burden into accounts unconstrained by the rules [59]. In addition, we recommend the authorities to review fiscal rules periodically in a non-political manner (as explained in Section 4.8) to avoid political interference.

\subsubsection{Incorporation of Natural Disasters/Climate Change}

Furthermore, our rules incorporate natural disasters and climate change shocks for the first time. As shown above, the debt target and the headline budget balance target already embed expected natural disaster shocks, taking into account their effects on debt dynamics. If there is a climate change or permanent natural disaster shock, the fiscal authorities can revise these fiscal targets. Specifically, we show that the effects of climatic 
change on the steady-state debt level can be either positive or negative, depending on the relative change in real interest rate and growth rate (Figure 5). Since natural disasters shocks are already embedded in the fiscal targets (i.e., debt and budget balance targets), the government can avoid both over-expenditure and under-budgeting stemming from the fiscal risks associated with natural disasters.

\subsubsection{Avoidance of Escape Clauses}

One contribution of our analysis is that we distinguish between the temporary natural disaster shocks and permanent shocks. Therefore, in contrast to the second-generation fiscal rules, our new natural disaster-resilient fiscal rule does not put all kinds of natural disasters into escape clauses. Otherwise, small island states may trigger escape clauses every year, and there will be no binding fiscal rules. This is very important for small island countries because triggering an escape clause involves a costly review process.

\subsubsection{Stabilization Fund}

The fiscal buffer for expected natural disasters $((s n /\{(1+r) /(1+y)-1\})$ in Equation (6)) is already included in the debt target, and amounts of deviation from the natural disasterresilient fiscal rule in good times are saved in stabilization fund following the budget balance adjustment rule defined in Equation (10). Therefore, the amount in the stabilization fund is determined by the fiscal rule in our policy framework, which is a stark contrast to the common practice in the Pacific Islands, as articulated in Section 4.5. It is important to note that this is very different from existing institutional view that small island countries should: (i) save enough funds before natural disasters occur; and (ii) use an escape clause to avoid fiscal rules once a disaster happens.

\subsubsection{Bindingness}

In our new fiscal rule framework, the rules are always effectively binding except the extreme situation in which climate change (or permanent natural disaster) shock changes the economy in the long-run steady state.

\subsubsection{Investment-Friendliness}

The recurrent expenditure and natural disaster-resilient fiscal rules are better than traditional expenditure rules since capping expenditure growth constrains government expenditure required for recovery of damages caused by disasters. The fiscal rules add a growth-friendliness dimension to the fiscal sustainability objective, provided public investment is productive [71]. Our investment-friendly natural disaster-resilient rule supports (re)building infrastructure (e.g., coastal protection) to meet its needs for protecting people and property from natural disasters/climate change. In addition, as explained above, the fiscal authority can choose the portion $\left(S_{t}\right)$ of disaster impact that the government wants to cover (i.e., the rest could be covered by private sector or international donors).

\subsubsection{Interconnectedness}

We also take a note of the fact that, in our proposed fiscal framework, fiscal targets (the debt target expressed in Equation (6) and the budget balance target shown in Equation (9)) and fiscal rules (the recurrent expenditure rule based on non-resource and non-grant revenue defined in Equation (12); the natural disaster-resilient fiscal rule incorporating debt and budget balance targets in Equation (14); and the linear budget balance adjustment rule presented in Equation (10)) are different concepts, although they are closely interconnected in our natural disaster-resilient fiscal framework. Thus, there is a direct link between expenditure and revenue, and, consequently, the level of overall balance is uniquely determined without computing GDP. This interconnectedness between budget items provides clear operation guidance for enforcement of natural disaster-resilient fiscal rule or recurrent spending rule. 


\subsubsection{Progressiveness}

Our natural disaster-resilient fiscal rule includes forward-looking element because it encompasses expected future natural disaster risks in the fiscal targets (e.g., debt target). Moreover, as discussed in Section 4.7, fiscal authorities are encouraged to demonstrate a forward-looking explanation mechanism by providing future fiscal path once the actual fiscal outcomes deviate from the rule. The fiscal authorities need to explain how natural disasters affect revenues, expenditures (including multi-year public investment planning), and debt projections in the medium term and what kind of fiscal consolidation plan is required to follow the adjustment rule-for instance, Equation (10). This effort will improve credibility and transparency of fiscal policy so that citizens can check and monitor the government's commitment to fiscal rules.

\subsubsection{Versatility}

Finally, note that our fiscal rule framework is also applicable to other types of shock, e.g., the terms-of-trade shock.

\subsubsection{Summary}

For these twelve reasons, the proposed natural disaster-resilient fiscal rule (defined as the recurrent expenditure rule based on non-resource and non-grant revenue, interdependently determined by government debt and head budget balance targets with expected disaster shocks) is very different from features of the second-generation fiscal rules, and we can perhaps call it "the third-generation fiscal rule." In summary, among the above-mentioned twelve new characteristics, the three most important elements of our third-generation fiscal rule are: (1) operational feasibility for the small developing states; (2) incorporation of natural disasters and climate change; and (3) unique interconnectedness between fiscal targets and rules as well as among budgetary items. Based on the author's discussion with policy-makers in the small islands in the Pacific region, our rules are much more practically and operationally useful for small states than any other existing fiscal rules. An advantage of practical feasibility should be tested by implementing our third-generation fiscal rule, especially the natural disaster-resilient fiscal rule, by the fiscal authorities in the small states around the world.

\subsection{Limitations of the Study and Future Research}

The limitation of this study is that available data for small islands are very limited. Therefore, in the future research, we suggest researchers to include not only the Pacific Islands but also small states in other regions, such as the Caribbean or Africa. This will improve the robustness of empirical findings, especially when estimating the fiscal reaction function for small states.

Another possible direction of future research is to study the relationship between natural disaster-resilient fiscal rule and other macroeconomic policies because fiscal rules can affect or be constrained by other sectors [72,73]. Although there are some papers that study the relationship between fiscal rules and monetary policy [74-79], few studies have analyzed its relationship with a policy to sustain financial stability, i.e., macroprudential policy [80]. Since sovereign debt default and the banking sector are highly interconnected, we need to study how natural disaster-resilient fiscal rule can contribute to the stability of banking system in the event of natural disasters. For instance, a countercyclical nature of the natural disaster-resilient fiscal rule will contribute to smoothing credit demand of the economy. Without natural disaster-resilient fiscal rule, there could be a twin sovereign debt and banking crisis when small states face massive and catastrophic natural disaster events. Unexpected shocks can also trigger a twin currency and banking crisis if the banking sector is taking an exchange rate risk [81] and the onset probability of a financial crisis depends on structural vulnerability and resilience of the economy $[82,83]$ and combinations with other macroeconomic policies $[84,85]$. This is important because natural disasters increase the likelihood of a banks' default, and the impact of a natural disaster depends on the size and 
scope of the catastrophe, financial regulation and supervision, and the level of financial and economic development of a country [86]. Thus, a suggested future research question is: "What kind of role does the natural disaster-resilient fiscal rule play to mitigate the amplification mechanism between the fiscal sector and the financial system when countries experience (catastrophic) natural disasters?"

\section{Conclusions}

In the face of an increasing frequency and magnitude of natural disasters amplified by climate change and related uncertainty, small developing states are calling for a new fiscal framework. To accommodate this request, specific fiscal rules for small islands vulnerable to natural disasters, climate change, and commodity price fluctuations, as well as foreign aid, are analyzed and discussed in this paper, using the Pacific island countries as an example. The Pacific island countries are highly vulnerable to natural disasters and climate change shocks. To handle such shocks, we propose fiscal policy framework that includes the expected impact of shocks on fiscal balances. We provide an analytical framework to calibrate the debt and budget balance targets and expenditure rules. Our theoretical framework shows that an appropriate level of debt target depends on individual country parameters. We demonstrate that these parameters can be affected by unexpected permanent climate change shocks. One of the main contributions of our paper is the analysis of the implication of permanent natural disaster shocks or climate change on the sustainable, steady-state debt-to-GDP ratio. Furthermore, alternative fiscal rules for commodity exporters based on permanent income hypothesis are discussed. We also use the example of PNG to demonstrate the practical application of our natural disaster-resilient fiscal rule framework as a guidance for policy-makers. We chose PNG because it is the largest economy in the Pacific Islands, it has all the characteristics of the region (commodity exporters, reliance on grants, frequent natural disasters, and climate change shocks), and we have available data. Our main argument is that the natural disaster-resilient fiscal rule (and the recurrent expenditure rule) may be the most practically useful fiscal rule in the Pacific Islands as a countercyclical policy tool to handle natural disasters, volatile resource revenues, and uncertain foreign grants. It would be useful to apply similar analytical methods to other Pacific, Caribbean, or Indian Ocean countries.

Funding: This research received no external funding.

Institutional Review Board Statement: Not applicable.

Informed Consent Statement: Not applicable.

Data Availability Statement: Publicly available datasets were analyzed in this study. This data can be found here: https://www.imf.org/en/Publications/WEO/weo-database/2019/October.

Acknowledgments: The author is grateful to the three anonymous reviewers for their comments and suggestions. The author also thanks Scott Roger, Mareta Tauaa Kaiteie, Jacinta Tipo Hesaie, Sandile Hlatshwayo, Si Guo, Hidetaka Nishizawa, Kazuaki Miyachi, Gee Hee Hong, Yuko Kinoshita, Hiroaki Miyamoto, Masahiro Nozaki, Dongyeol Lee, Elena Loukoianova, Guohua Huang, Hideaki Matsuoka, Giovanni Ganelli, Rui Xu, Alison Margaret Stuart, Nikolay Gueorguiev, Futoshi Narita, Grant Johnston, Sali David, Laura Doherty, Paulo Medas, Carlo Pizzinelli, Julien Reynaud, Fazeer Sheik, Niklas Johan Westelius, Shinji Ayuha, Geoffrey Bannister, Hisahiro Naito, Motohiro Sato, Shinji Yamashige, Masako Ii, Satoshi Watanabe, the participants of the Small States Seminar held at the IMF, the participants of the Program in Economic and Public Policy Special Seminar held at the University of Tsukuba, the participants in the Public Economics Workshop held at Hitotsubashi University, officials from the Papua New Guinea Department of Treasury and the Bank of Papua New Guinea who attended my seminar in Port Moresby, and Cook Islands authorities that I met during the technical assistance mission for very useful discussions and comments, as well as Medha Madhu Nair for editorial assistance.

Conflicts of Interest: The author declares no conflict of interest. 
Disclosure Statement: The views expressed here are those of the author's and do not reflect those of the institution to which the author belongs. This article is a refereed and substantially extended version of [87].

\section{References}

1. Nakatani, R. A Possible Approach to Fiscal Rules in Small Islands-Incorporating Natural Disasters and Climate Change; IMF: Washington, DC, USA, 2019; Working Paper No. 19/186.

2. Nakatani, R. External Adjustment in a Resource-Rich Economy: The Case of Papua New Guinea; IMF: Washington, DC, USA, 2017; Working Paper No. 17/267.

3. Nakatani, R. Adjustment to negative price shocks by a commodity exporting economy: Does exchange rate flexibility resolve a balance of payments crisis? J. Asian Econ. 2018, 57, 13-35. [CrossRef]

4. Noy, I. Natural disasters in the pacific island countries: New measurements of impacts. Nat. Hazards 2016, 84, S7-S18. [CrossRef]

5. Brown, R.; Leeves, G.; Prayaga, P. Sharing norm pressures and community remittances: Evidence from a natural disaster in the Pacific Islands. J. Dev. Stud. 2014, 50, 383-398. [CrossRef]

6. Yang, D. Coping with disaster: The impact of hurricanes on international financial flows, 1970-2002. BE J. Econ. Anal. Policy 2008, 8, 13. [CrossRef]

7. Samuwai, J.; Hills, J. Assessing climate finance readiness in the Asia-Pacific region. Sustainability 2018, 10, 1192. [CrossRef]

8. Taupo, T.; Cuffe, H.; Noy, I. Household vulnerability on the frontline of climate change: The Pacific atoll nation of Tuvalu. Environ. Econ. Policy Stud. 2018, 20, 705-739. [CrossRef]

9. Noy, I. The macroeconomic consequences of disasters. J. Dev. Econ. 2009, 88, 221-231. [CrossRef]

10. Nakatani, R. Output Costs of Currency Crises: Shocks, Policies and Cycles; University Library of Munich: Munich, Germany, 2018; MPRA Paper No. 83549.

11. Nakatani, R. Output costs of currency crisis and banking crisis: Shocks, policies and cycles. Comp. Econ. Stud. 2019, 61, 83-102. [CrossRef]

12. Frankel, J.; Vegh, C.; Vuletin, G. On graduation from fiscal procyclicality. J. Dev. Econ. 2013, 100, 32-47. [CrossRef]

13. Noy, I.; Nualsri, A. Fiscal storms: Public spending and revenues in the aftermath of natural disasters. Environ. Dev. Econ. 2011, 16, 113-128. [CrossRef]

14. Klomp, J. Financial fragility and natural disasters: An empirical analysis. J. Financ. Stabil. 2014, 13, 180-192. [CrossRef]

15. Veld, J.; Larch, M.; Vandeweyer, M. Automatic fiscal stabilisers: What they are and what they do. Open Econ. Rev. 2013, 24, 147-163. [CrossRef]

16. Beer, D.; Mavalwalla, J. The BoC-BoE Sovereign Default Database Revisited: What's New in 2018? Bank of Canada: Ottawa, ON, Canada, 2018; Staff Working Paper No. 2018-30.

17. McDermott, T.; Barry, F.; Tol, R. Disasters and development: Natural disasters, credit constraints, and economic growth. Oxf. Econ. Pap. 2014, 66, 750-773. [CrossRef]

18. Sacchi, A.; Salotti, S. The impact of national fiscal rules on the stabilisation function of fiscal policy. Eur. J. Political Econ. 2015, 37, 1-20. [CrossRef]

19. Heinemann, F.; Moessinger, M.; Yeter, M. Do fiscal rules constrain fiscal policy? A meta-regression-analysis. Eur. J. Political Econ. 2018, 51, 69-92. [CrossRef]

20. Badinger, H.; Reuter, W. The case for fiscal rules. Econ. Model. 2017, 60, 334-343. [CrossRef]

21. Bergman, M.; Hutchison, M. Fiscal procyclicality in emerging markets: The role of institutions and economic conditions. Int. Financ. 2020, 23, 196-214. [CrossRef]

22. Bergman, M.; Hutchison, M. Economic Stabilization in the Post-Crisis World: Are Fiscal Rules the Answer? J. Int. Money Financ. 2015, 52, 82-101. [CrossRef]

23. Bergman, M.; Hutchison, M.; Jensen, S. Promoting sustainable finances in the European Union: The role of fiscal rules and government efficiency. Eur. J. Political Econ. 2016, 44, 1-19. [CrossRef]

24. Asatryan, Z.; Castellón, C.; Stratmann, T. Balanced budget rules and fiscal outcomes: Evidence from historical constitutions. J. Public Econ. 2018, 167, 105-119. [CrossRef]

25. Tapsoba, R. Do National numerical fiscal rules really shape fiscal behaviours in developing countries? A treatment effect evaluation. Econ. Model. 2012, 29, 1356-1369. [CrossRef]

26. Cordes, T.; Kinda, T.; Muthoora, P.; Weber, A. Expenditure Rules: Effective Tools for Sound Fiscal Policy? IMF: Washington, DC, USA, 2015; Working Paper No. 15/29.

27. Tran, N. Debt threshold for fiscal sustainability assessment in emerging economies. J. Policy Model. 2018, 40, 375-394. [CrossRef]

28. Baharumshah, Z.; Soon, S.; Lau, E. Fiscal sustainability in an emerging market economy: When does public debt turn bad? J. Policy Model. 2017, 39, 99-113. [CrossRef]

29. Greenidge, K.; Craigwell, R.; Thomas, C.; Drakes, L. Threshold Effects of Sovereign Debt: Evidence from the Caribbean; IMF: Washington, DC, USA, 2012; Working Paper No. 12/157.

30. Khalladi, H. Fiscal fatigue, public debt limits and fiscal space in some MENA Countries. Econ. Bull. 2019, 39, $1005-1017$.

31. Onofrei, M.; Gavriluţă, A.; Bostan, I.; Oprea, F.; Paraschiv, G.; Lazăr, C. The implication of fiscal principles and rules on promoting sustainable public finances in the EU countries. Sustainability 2020, 12, 2772. [CrossRef] 
32. Bitar, N.; Chakrabarti, A.; Zeaiter, H. Were reihart and rogoff right? Int. Rev. Econ. Financ. 2018, 58, 614-620. [CrossRef]

33. Lee, S.; Park, H.; Seo, M.; Shin, Y. Testing for a debt-threshold effect on output growth. Fisc. Stud. 2017, 38, 701-717. [CrossRef] [PubMed]

34. Checherita-Westphal, C.; Hallett, A.; Rother, P. Fiscal sustainability using growth-maximizing debt targets. Appl. Econ. 2014, 46, 638-647. [CrossRef]

35. Taupo, T. Sustainable financing for climate and disaster resilience in atoll islands: Evidence from Tuvalu and Kiribati. Pac. Econ. Rev. 2019, 24, 705-717. [CrossRef]

36. Jayaraman, T.; Lau, E. Does external debt lead to economic growth in Pacific Island Countries. J. Policy Model. 2009, 31, $272-288$. [CrossRef]

37. Minea, A.; Villieu, P. Borrowing to finance public investment? The 'golden rule of public finance' reconsidered in an endogenous growth setting. Fisc. Stud. 2009, 30, 103-133. [CrossRef]

38. Bom, P. Fiscal rules and the intergenerational welfare effects of public investment. Econ. Model. 2019, 81, 455-470. [CrossRef]

39. Dessus, S.; Diaz-Sanchez, J.; Varoudakis, A. Fiscal rules and the pro-cyclicality of public investment in the West African economic and monetary union. J. Int. Dev. 2016, 28, 887-901. [CrossRef]

40. Eyraud, L.; Debrun, X.; Hodge, A.; Lledo, V.; Pattillo, C. Second-Generation Fiscal Rules; Balancing Simplicity, Flexibility, and Enforceability; IMF: Washington, DC, USA, 2018; Staff Discussion Notes No. 2018/004.

41. Ghosh, A.; Kim, J.; Mendoza, E.; Ostry, J.; Qureshi, M. Fiscal fatigue, fiscal space and debt sustainability in advanced economies Econ. J. 2013, 123, F4-F30. [CrossRef]

42. Ganiko, G.; Melgarejo, K.; Montoro, C. How Much Is Too Much? The Fiscal Space in Emerging Market Economies; Central Reserve Bank of Peru: Lima, Peru, 2016; Working Paper 2016-014.

43. IMF. World Economic Outlook Database, October 2019; IMF: Washington, DC, USA, 2019.

44. Noy, I.; Edmonds, C. Increasing fiscal resilience to disasters in the Pacific. Nat. Hazards 2019, 97, 1375-1393. [CrossRef]

45. Lee, D.; Zhang, H.; Nguyen, C. The Economic Impact of Natural Disasters in Pacific Island Countries: Adaptation and Preparedness; IMF: Washington, DC, USA, 2018; Working Paper No. 18/108.

46. Lis, E.; Nickel, C. The impact of extreme weather events on budget balances. Int. Tax Public Financ. 2010, 17, 378-399. [CrossRef]

47. Halac, M.; Yared, P. Fiscal rules and discretion under persistent shocks. Econometrica 2014, 82, 1557-1614.

48. Kousky, C. Informing climate adaptation: A review of the economic costs of natural disasters. Energy Econ. 2014, 46, 576-592. [CrossRef]

49. Lazzaroni, S.; van Bergeijk, P. Natural disasters' impact, factors of resilience and development: A meta-analysis of the macroeconomic literature. Ecol. Econ. 2014, 107, 333-346. [CrossRef]

50. Skidmore, M.; Toya, H. Do Natural disasters promote long-run growth? Econ. Inq. 2002, 40, 664-687. [CrossRef]

51. Loayza, N.; Olaberría, E.; Rigolini, J.; Christiaensen, L. Natural disasters and growth: Going beyond the averages. World Dev. 2012, 40, 1317-1336. [CrossRef]

52. Cunado, J.; Ferreira, S. The macroeconomic impacts of natural disasters: The case of floods. Land Econ. 2014, 90, 149-168. [CrossRef]

53. Cavallo, E.; Galiani, S.; Noy, I.; Pantano, J. Catastrophic natural disasters and economic growth. Rev. Econ. Stat. 2013, 95, 1549-1561. [CrossRef]

54. Felbermayr, G.; Gröschl, J. Naturally negative: The growth effects of natural disasters. J. Dev. Econ. 2014, 111, 92-106. [CrossRef]

55. Klomp, J. Sovereign risk and natural disasters in emerging markets. Emerg. Mark. Financ. Trade 2015, 51, 1326-1341. [CrossRef]

56. Hallett, A.; Kattai, R.; Lewis, J. How reliable are cyclically adjusted budget balances in real time? Contemp. Econ. Policy 2012, 30, 75-92. [CrossRef]

57. Becerra, O.; Cavallo, E.; Noy, I. Foreign aid in the aftermath of large natural disasters. Rev. Dev. Econ. 2014, 18, 445-460. [CrossRef]

58. Becerra, O.; Cavallo, E.; Noy, I. Where is the money? Post-disaster foreign aid flows. Environ. Dev. Econ. 2015, 20, 561-586. [CrossRef]

59. Burret, H.; Feld, L. (Un-) intended effects of fiscal rules. Eur J. Political Econ. 2018, 52, 166-191. [CrossRef]

60. Van der Ploeg, R. Guidelines for exploiting natural resource wealth. Oxf. Rev. Econ. Policy 2014, 30, 145-169. [CrossRef]

61. Marto, R.; Papageorgiou, C.; Klyuev, V. Building resilience to natural disasters: An application to small developing states. J. Dev. Econ. 2018, 135, 574-586. [CrossRef]

62. Yared, P. Rising government debt: Causes and solutions for a decades-old trend. J. Econ. Perspect. 2019, 33, 115-140. [CrossRef]

63. Guerguil, M.; Mandon, P.; Tapsoba, R. Flexible fiscal rules and countercyclical fiscal policy. J. Macroecon. 2017, 52, 189-220. [CrossRef]

64. Combes, J.; Minea, A.; Sow, M. Is fiscal policy always counter- (pro-) cyclical? The role of public debt and fiscal rules. Econ. Model. 2017, 65, 138-146. [CrossRef]

65. Jalles, J. Fiscal rules and fiscal counter-cyclicality. Econ. Lett. 2018, 170, 159-162. [CrossRef]

66. Tóth, C. Valuable legacy? The effects of inherited fiscal rules. Public Choice 2019, 178, 3-30. [CrossRef]

67. Gootjes, B.; de Haan, J.; Jong-A-Pin, R. Do fiscal rules constrain political budget cycles? Public Choice 2020. [CrossRef]

68. Reuter, W. When and why do countries break their national fiscal rules? Eur. J. Political Econ. 2019, 57, 125-141. [CrossRef]

69. Beetsma, R.; Debrun, X.; Fang, X.; Kim, Y.; Lledó, V.; Mbaye, S.; Zhang, X. Independent fiscal councils: Recent trends and performance. Eur. J. Political Econ. 2019, 57, 53-69. [CrossRef] 
70. Wyplosz, C. Fiscal discipline: Rules rather than institutions. Natl. Inst. Econ. Rev. 2011, 217, R19-R30. [CrossRef]

71. Ardanaz, M.; Cavallo, E.; Izquierdo, A.; Puig, J. Growth-friendly fiscal rules? Safeguarding public investment from budget cuts through fiscal rule design. J. Int. Money Financ. 2021, 111, 102319. [CrossRef]

72. Portes, J.; Wren-Lewis, S. Issues in the design of fiscal policy rules. Manch. Sch. 2015, 83, 56-86. [CrossRef]

73. Badinger, H.; Fichet de Clairfontaine, A.; Reuter, W. Fiscal rules and twin deficits: The link between fiscal and external balances. World Econ. 2017, 40, 21-35. [CrossRef]

74. Schmitt-Grohé, S.; Uribe, M. Optimal simple and implementable monetary and fiscal rules. J. Monet. Econ. 2007, 54, 1702-1725. [CrossRef]

75. Ferrero, A. Fiscal and monetary rules for a currency union. J. Int. Econ. 2009, 77, 1-10. [CrossRef]

76. Motta, G.; Tirelli, P. Optimal simple monetary and fiscal rules under limited asset market participation. J. Money Credit Bank. 2012, 44, 1351-1374. [CrossRef]

77. Leeper, E. Should Central Banks Care About Fiscal Rules? National Bureau of Economic Research: Cambridge, MA, USA, 2016; Working Paper 22800.

78. Ryoo, S.; Skott, P. Fiscal and monetary policy rules in an unstable economy. Metroeconomica 2017, 68, 500-548. [CrossRef]

79. Combes, J.; Debrun, X.; Minea, A.; Tapsoba, R. Inflation targeting, fiscal rules and the policy mix: Cross-effects and interactions. Econ. J. 2018, 128, 2755-2784. [CrossRef]

80. Nakatani, R. Macroprudential policy and the probability of a banking crisis. J. Policy Model. 2020, 42, 1169-1186. [CrossRef]

81. Nakatani, R. Twin banking and currency crises and monetary policy. Open Econ. Rev. 2016, 27, 747-767. [CrossRef]

82. Nakatani, R. The Effects of Financial and Real Shocks, Structural Vulnerability and Monetary Policy on Exchange Rates from the Perspective of Currency Crises Models; University of Tokyo: Tokyo, Japan, 2014; UTokyo Price Project Working Paper No. 61; Available online: http:/ / www.price.e.u-tokyo.ac.jp/img/researchdata/pdf/p_wp061.pdf (accessed on 10 March 2021).

83. Nakatani, R. Structural vulnerability and resilience to currency crisis: Foreign currency debt versus export. N. Am. J. Econ. Financ. 2017, 42, 132-143. [CrossRef]

84. Nakatani, R. The effects of productivity shocks, financial shocks, and monetary policy on exchange rates: An application of the currency crisis model and implications for emerging market crises. Emerg. Mark. Financ. Trade 2017, 53, 2545-2561. [CrossRef]

85. Nakatani, R. Real and financial shocks, exchange rate regimes and the probability of a currency crisis. J. Policy Model. 2018, 40, 60-73. [CrossRef]

86. Klomp, J. Flooded with debt. J. Int. Money Financ. 2017, 73, 93-103. [CrossRef]

87. Nakatani, R. Fiscal Rules for Natural Disaster- and Climate Change-Prone Small States; University Library of Munich: Munich, Germany, 2021; MPRA Paper No. 106020. 